\title{
Implications of Using On-Farm Flood Flow Capture To Recharge Groundwater and Mitigate Flood Risks Along the Kings River, CA.
}

In fulfillment of Deliverable:

3c. Technical Analyses

And

4a. Final Report

For Grant Agreement No. 68-9104-0-128

between

Bachand \& Associates

and the

United States Department of Agriculture

Natural Resources Conservation Service

September 30, 2012

P.A.M. Bachand ${ }^{1}$, W.R. Horwath ${ }^{3}$, S. Roy ${ }^{5}$, J. Choperena ${ }^{4}$, and D. Cameron ${ }^{2}$ ${ }^{1}$ Bachand \& Associates, Davis, CA 95618; ${ }^{2}$ Terranova Ranch; ${ }^{3}$ University of California Davis, ${ }^{4}$ Sustainable Conservation; ${ }^{5}$ Tetra Tech, Lafayette 
On-Farm Flood Flow Capture As a Cost Effective Method to Recharge Groundwater and Reduce Downstream Flood Risks

Agreement No. 68-9104-128

\section{Contents}

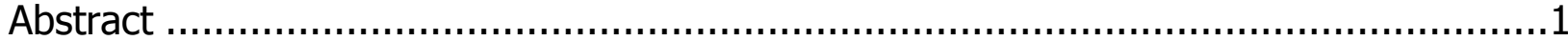

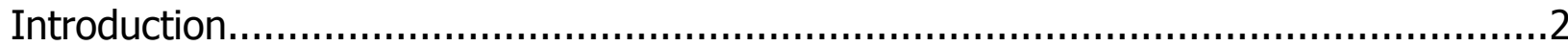

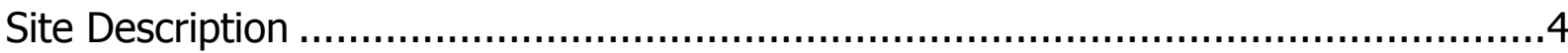

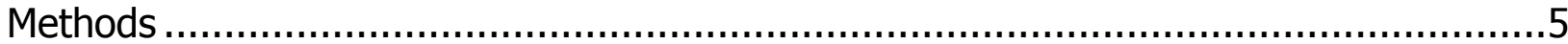

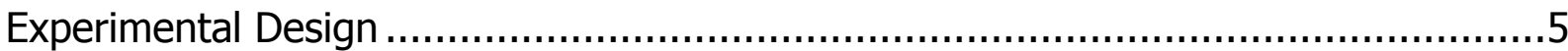

Field Activities Required for Capturing and Applying Flood Flows ...........................5

Daily Infiltration Rates and Seasonal Totals .................................................... 6

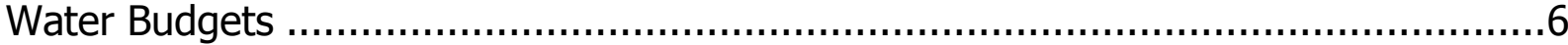

Water Quality, Soils Analyses and Soils Mass Budgets .......................................6

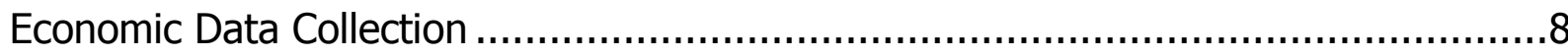

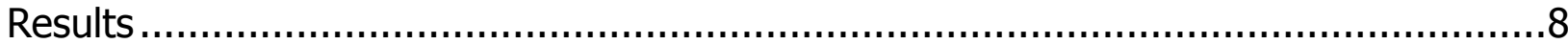

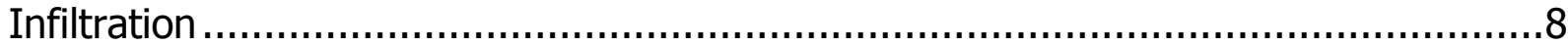

Surface and Subsurface Water Quality and Soils .............................................. 8

Surface Water Budget.................................................................................... 10

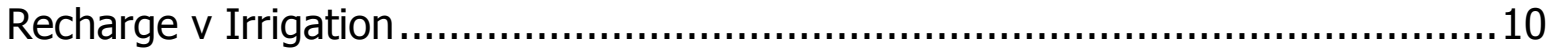

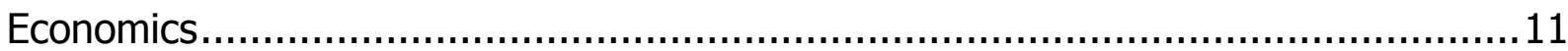

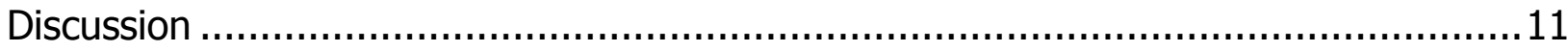

Soil Series and Predicting Infiltration on Agricultural Lands................................11

Saturated zone hydrologic and salinity budget and implications on groundwater

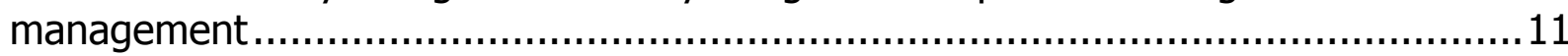

Considerations for Regional and Local Implementation Logistics ........................... 14

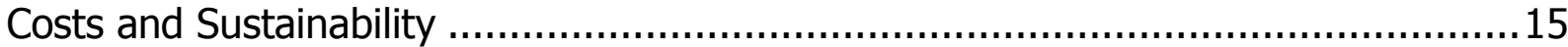

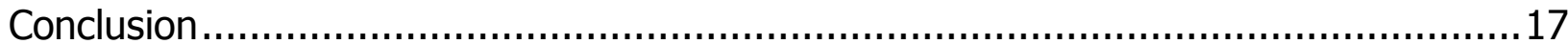

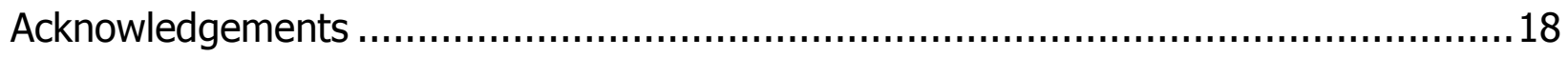

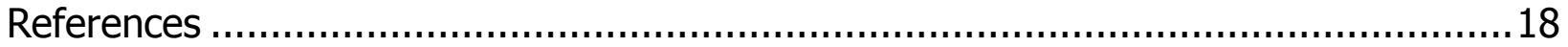

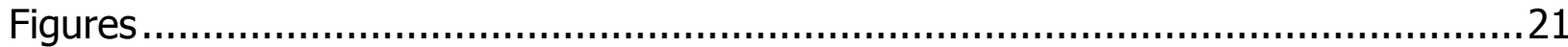

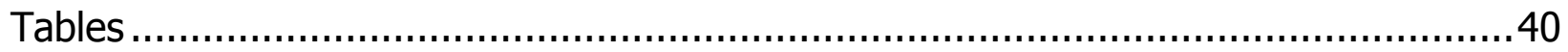


On-Farm Flood Flow Capture As a Cost Effective Method to Recharge Groundwater and Reduce Downstream Flood Risks

Agreement No. 68-9104-128

\section{Figures}

Figure 1. Hydrologic Features of the Kings River........................................... 22

Figure 2. Boring Log Summary for Recharge Feasibility Study, $0-100 \mathrm{ft} . \ldots \ldots \ldots \ldots . . .23$

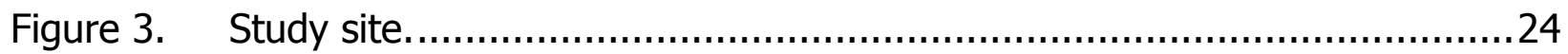

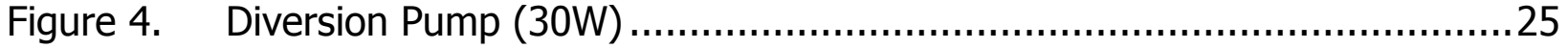

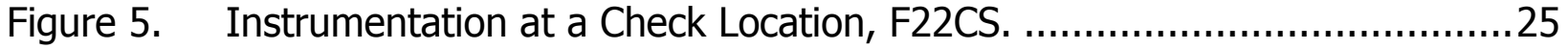

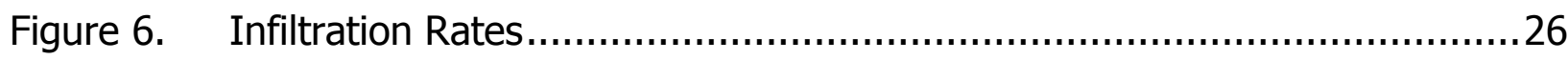

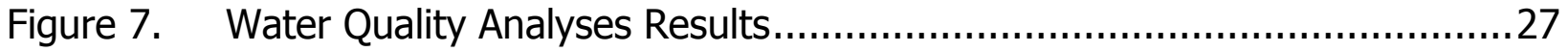

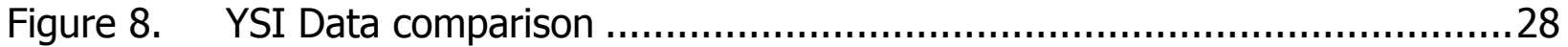

Figure 9. Soil moisture in response to April through June recharge activities at

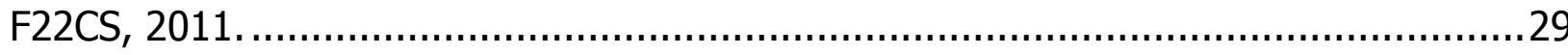

Figure 10. Measured changes in EC (ds/M) at F21CS replicates at depths of 6, 24 and

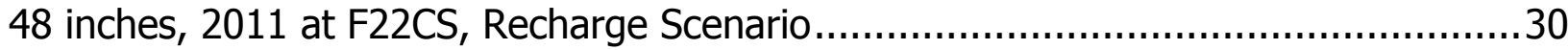

Figure 11. Measured changes in EC (ds/M) at F21CS replicates at depths of 6, 24 and 48 inches, 2011, at F21CS, over-irrigation scenario.

Figure 12. Nitrate in top 120 inches of the soil layer, November 2011 - post irrigation 32

Figure 13. Geoprobe pore water EC and nitrate concentrations with Depth 33

Figure 14. Kings River flows diverted into Terranova through the turnout and past the James Weir into the James Bypass, 2011/12.

Figure 15. Monthly water applied and ETc losses for Key Fields, January - July 201135

Figure 16. Conceptual Model of Nitrate and Salt movement during annual periods of

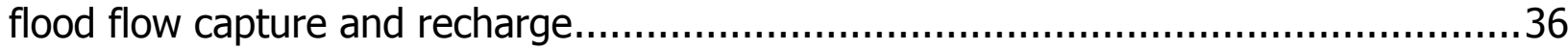

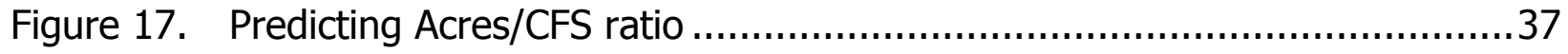

Figure 18. Costs of Combined Irrigation and Direct Recharge ................................ 37

Figure 19. Flows past the James Bypass represent excess flood flows from the Kings

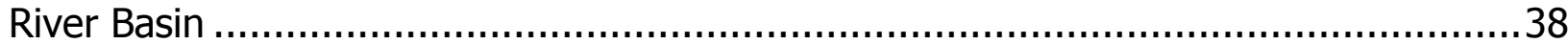




\section{Tables}

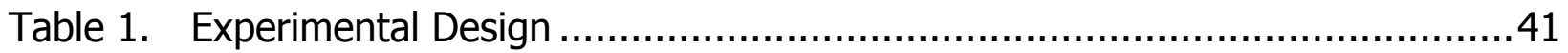

Table 2. Turnout Monthly Volumes ............................................................ 42

Table 3. Laboratory Method Summary......................................................... 42

Table 4. Statistical Differences between treatments for infiltration rates (in/d). ........43

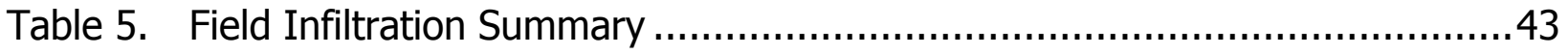

Table 6. Acre Feet Applied by Crop and Field ....................................................4

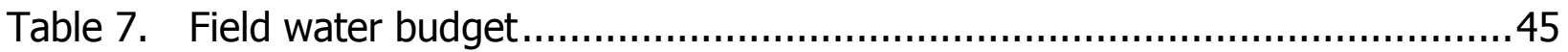

Table 8. Monthly Water Budget for three key crops ............................................ 46

Table 9. Farm Costs Summary from January through July, 2012...........................47

Table 10. Summary of hydrologic characteristics of soil series ..............................48

Table 11. Pumped groundwater quality at a sample of Terranova Ranch wells, 2007 200949

Table 12. Salt Mass Budget from Profile.................................................... 50

Table 13. Infiltration Acres to Capture Flood Flows past the James Bypass for Soils of Different Hydrologic Groups............................................................................ 51

Table 14. Local and Regional Logistical Issues............................................... 52

Table 15. Recurrence Intervals and Flows for High Flow in the Kings River .............53 


\title{
Implications of Using On-Farm Flood Flow Capture To Recharge Groundwater and Mitigate Flood Risks Along the Kings River, CA.
}

\author{
P.A.M. Bachand ${ }^{1}$, W.R. Horwath ${ }^{3}$ S. Roy ${ }^{5}$, J. Choperena ${ }^{4}$, and D. Cameron ${ }^{2}$, \\ ${ }^{1}$ Bachand \& Associates, Davis, CA 95618; ${ }^{2}$ Terranova Ranch; ${ }^{3}$ University of California \\ Davis, ${ }^{4}$ Sustainable Conservation; ${ }^{5}$ Tetra Tech, Lafayette, CA
}

\section{Abstract}

Two large hydrologic issues face the Kings Basin, severe and chronic overdraft of about $0.16 \mathrm{M}$ ac-ft annually, and flood risks along the Kings River and the downstream San Joaquin River. Since 1983, these floods have caused over \$1B in damage in today's dollars. Capturing flood flows of sufficient volume could help address these two pressing issues which are relevant to many regions of the Central Valley and will only be exacerbated with climate change. However, the Kings River has high variability associated with flow magnitudes which suggests that standard engineering approaches and acquisition of sufficient acreage through purchase and easements to capture and recharge flood waters would not be cost effective. An alternative approach investigated in this study, termed On-Farm Flood Flow Capture, involved leveraging large areas of private farmland to capture flood flows for both direct and in lieu recharge. This study investigated the technical and logistical feasibility of best management practices (BMPs) associated with On-Farm Flood Flow Capture. The investigation was conducted near Helm, CA, about 20 miles west of Fresno, CA.

The experimental design identified a coordinated plan to determine infiltration rates for different soil series and different crops; develop a water budget for water applied throughout the program and estimate direct and in lieu recharge; provide a preliminary assessment of potential water quality impacts; assess logistical issues associated with implementation; and provide an economic summary of the program. At check locations, we measured average infiltration rates of $4.2 \mathrm{in} / \mathrm{d}$ for all fields and noted that infiltration rates decreased asymptotically over time to about $2-2.5 \mathrm{in} / \mathrm{d}$. Rates did not differ significantly between the different crops and soils tested, but were found to be about an order of magnitude higher in one field. At a $2.5 \mathrm{in} / \mathrm{d}$ infiltration rate, 100 acres are required to infiltrate 10 CFS of captured flood flows.

Water quality of applied flood flows from the Kings River had concentrations of COC (constituents of concern; i.e. nitrate, electrical conductivity or EC, phosphate, ammonium, total dissolved solids or TDS) one order of magnitude or more lower than for pumped groundwater at Terranova Ranch and similarly for a broader survey of regional groundwater. Applied flood flows flushed the root zone and upper vadose zone of nitrate and salts, leading to much lower EC and nitrate concentrations to a depth of 8 feet when compared to fields in which more limited flood flows were applied or for which drip irrigation with groundwater was the sole water source.

In demonstrating this technology on the farm, approximately 3,100 ac-ft was diverted, primarily from April through mid-July, with about $70 \%$ towards in lieu and $30 \%$ towards 
On-Farm Flood Flow Capture As a Cost Effective Method to Recharge Groundwater and Reduce Downstream Flood Risks

Agreement No. 68-9104-128

direct recharge. Substantial flood flow volumes were applied to alfalfa, wine grapes and pistachio fields. A subset of those fields, primarily wine grapes and pistachios, were used primarily to demonstrate direct recharge. For those fields about $50-75 \%$ of water applied was calculated going to direct recharge. Data from the check studies suggests more flood flows could have been applied and infiltrated, effectively driving up the amount of water towards direct recharge.

Costs to capture flood flows for in lieu and direct recharge for this project were low compared to recharge costs for other nearby systems and in comparison to irrigating with groundwater. Moreover, the potentially high flood capture capacity of this project suggests significant flood avoidance costs savings to downstream communities along the Kings and San Joaquin Rivers. Our analyses for Terranova Ranch suggest that allocating $25 \%$ or more flood flow water towards in lieu recharge and the rest toward direct recharge will result in an economically sustainable recharge approach paid through savings from reduced groundwater pumping.

Two important issues need further consideration. First, these practices are likely to leach legacy salts and nitrates from the unsaturated zone into groundwater. We develop a conceptual model of EC movement through the unsaturated zone and estimated through mass balance calculations that approximately $10 \mathrm{~kg} / \mathrm{m}^{2}$ of salts will be flushed into the groundwater through displacing $12 \mathrm{~m}^{3} / \mathrm{m}^{2}$ of unsaturated zone pore water. This flux would increase groundwater salinity but an equivalent amount of water added subsequently is predicted as needed to return to current groundwater salinity levels. All subsequent flood flow capture and recharge is expected to further decrease groundwater salinity levels. Second, the project identified important farm-scale logistical issues including irrigator training; developing cropping plans to integrate farming and recharge activities; upgrading conveyance; and quantifying results. Regional logistical issues also exist related to conveyance, integration with agricultural management, economics, required acreage and Operation and Maintenance (O\&M).

\section{Introduction}

Agriculture within the Kings Basin relies heavily on both surface water and groundwater to meet irrigation needs to meet its annual $2.7 \mathrm{M}$ ac-ft demand. Surface water deliveries vary annually, ranging from about 0.3 to $1.5 \mathrm{M}$ ac-ft and averaging around $1 \mathrm{M}$ ac-ft (WRIME 2007). One million to $2.2 \mathrm{M}$ ac-ft is pumped from groundwater, averaging about 1.6M ac-ft. WRIME (2007) calculated all sources of water to the Kings Basin including deep percolation from the east and south, and estimated overdraft in the Kings Basin at about $0.16 \mathrm{M}$ ac-ft annually, with about $0.1 \mathrm{M}$ ac-ft overdraft from the Lower Kings Basin and 0.06M ac-ft overdraft from the Upper Kings Basin.

Severe and chronic groundwater overdraft has resulted in lower groundwater levels in the region. Groundwater levels have dropped most dramatically, dropping $60-80$ feet near Helm (WRIME, 2007). Since irrigation in the region is primarily through pumping groundwater, the need for pumping from 200 feet below the surface creates severe economic pressure in the region, with costs to utilize that water at about $\$ 90 / \mathrm{ac}-\mathrm{ft}$ (Cameron, personal communication; James Irrigation District 2010). 
On-Farm Flood Flow Capture As a Cost Effective Method to Recharge Groundwater and Reduce Downstream Flood Risks

Agreement No. 68-9104-128

Large parts of California face this challenge. California overdrafts $1-2 \mathrm{M}$ ac- $\mathrm{ft}$ annually to meet $30-40 \%$ of its urban and agricultural water demand (DWR 2003). More than $70 \%$ of California's overdraft occurs in the Central Valley's Sacramento, San Joaquin and Tulare Basins (DWR 2003) where over 7 million acres of agriculture are irrigated (Reclamation 2012). In the Sacramento River Hydrologic Region (HR), 2.7M ac-feet of groundwater overdraft meet $31 \%$ of total agricultural and municipal water demand; in the San Joaquin River HR 2.2M ac-ft of groundwater overdraft meet 30\% total water demand; and in the Tulare River HR 4.3M ac-feet of groundwater overdraft meet $41 \%$ of total water demand (DWR 2003).

Given the surface water shortage over an annual time frame, the Kings Basin ironically faces flooding risks as well. Flooding can occur from around January through July due to releases from Pine Flat Reservoir. These releases occur in anticipation of achieving reservoir capacity and accommodating snowmelt runoff in the Sierra Nevada.

Consequently, resulting flows downstream of the dam are highly variable. At the James Weir, flow occurs $14 \%$ of the time with a 2-year with an average duration of 104 days (Bachand, 2011). Over a 42-year USGS record, flood flows have been evenly distributed from 500 to 5,500 CFS with a median of 1560 CFS for times when flood flows are occurring. Flows have exceeded the 4,750 CFS design criteria on a 7-year recurrence interval and have an average duration of 33 days. Up to $2 \mathrm{M}$ ac-ft can pass the James Weir annually and for years when flows are occurring, the median volume passing the James Weir is $0.19 \mathrm{M}$ ac-ft.

From 1967 to 1997, three large flood events caused significant damage along the SJR system: 1983 - \$324M, 1995 - \$193M, 1997 - \$223M. In today's dollars, total damages from these floods exceeded $\$ 1.2 \mathrm{~B}$.

Climate change will exacerbate both hydrologic challenges: groundwater overdraft and flood risks. More variation in average precipitation is expected from model projections for California watersheds (Reclamation 2011; World Climate Research Programme's (WCRP's) Coupled Model Intercomparison Project phase 3 (CMIP3) multi-model dataset). Potential impacts could involve more variable precipitation, a larger fraction of the precipitation occurring as rain rather than snow, earlier runoff, and greater incidence of rain on snow events (DWR 2003; Thorne 2012). These impacts will cause increased variability in the magnitude and frequency of river flows, including flood flows, and thus challenge California's current hydrologic system of dams and reservoirs with regard to managing flood risks and water supply. Structural and operational adjustments are likely needed to adjust to these climate change impacts. Increasing groundwater recharge capacity is considered to be a cost effective and effective tool to meet this challenge (Tetra Tech 2011; Langridge et al 2012).

Over the last two decades, efforts are underway in the Kings Basin to address groundwater and flooding problems. Farmers and landowners have worked with Kings River Conservation District (KRCD), Kings River Water Association (KRWA) and other water agencies to develop recharge strategies and facilities. Near the James Bypass, engineered recharge basins on 67 dedicated acres were proposed to capture $230-800$ ac-ft of stormwater monthly (during stormflows) and provide an additional 2,000 ac-ft 
On-Farm Flood Flow Capture As a Cost Effective Method to Recharge Groundwater and Reduce Downstream Flood Risks

Agreement No. 68-9104-128

of in lieu recharge and dormant flooding (KRCD 2000, 2006). Infiltration tests estimated rates at about 2 inches/day. Initial efforts to develop a regional conjunctive use program as part of the Kings Basin Integrated Regional Management Plan (IRWMP) were completed in December 2006 with the Kings Basin Conjunctive Use Feasibility Analysis (WRIME 2006), recommending acquiring 2,600 recharge acres through acquisition and easements.

However, these solutions have lacked the flexibility and capacity to address the variability and magnitude of these hydrologic challenges. Reliance on dedicated public lands, acquisition of private lands or easements, and hard engineering approaches are likely to lack the flexibility and capacity to sufficiently address these problems in an affordable way. Thousands of acres may be required and land or easement acquisition costs and engineering requirements are expected to make these solutions too expensive. We have studied an alternative with diverting flood flows onto dual use agricultural lands (i.e., agriculture as well as flood management), investigating the feasibility of this approach both technically and logistically. This study has quantified flood flow capture rates that can be achieved; investigated potential water quality issues; identified and addressed logistical challenges; and conducted a preliminary economic assessment of costs. We provide this feasibility study as the initial assessment of this technology as a potential solution for areas in the Central Valley and in other regions where similar challenges are faced.

\section{Site Description}

This investigation was conducted on 1,000 acres of Terranova Ranch located in western Fresno County. The ranch lies adjacent to the James Bypass, a section of the Kings River beginning at the James Weir. Flow in the river from Pine Flat Reservoir at the base of the Sierra westward is jointly managed by the Kings River Water Association (KRWA) and the Army Corps of Engineers through management of the reservoir for flood control and allocation to downstream users (Figure 1). Releases occur in anticipation of achieving reservoir capacity and accommodating snowmelt runoff in the Sierra Nevada. This requirement can lead to flooding downstream of the dam during the months of December to July. The James Weir is 16 miles upstream of the Mendota Pool at the confluence of the Kings and San Joaquin Rivers (Figure 1).

A large variety of crops, including vineyard, orchard, field and row crops, are grown at Terranova Ranch. Groundwater is the primary irrigation source, applied through drip and flood irrigation systems. The ranch is in a Mediterranean climate and receives an average of 11 inches of rain annually.

Our study site primarily overlays sandy loams and loamy sands, some of it typically overlaying a cemented duripan $1.5-3$ feet down. Soil cores in the area show silty clay and clay lenses from $0-100$ feet (Figure 2 ). The pilot study was conducted on a subset of the farm over about 1000 acres (Figure 3). 
On-Farm Flood Flow Capture As a Cost Effective Method to Recharge Groundwater and Reduce Downstream Flood Risks

Agreement No. 68-9104-128

\section{Methods}

We describe below the methods used to 1) quantify achievable infiltration rates; 2) develop a water budget for the study area to estimate direct and in lieu recharge; 3) assess potential water quality effects; and 4) develop economic data.

\section{Experimental Design}

Table 1 details the experimental design implemented for this project. The table identifies the fields in which experimental investigations were conducted, identifying soils and crops. For each field methods are identified related to estimating in situ infiltration rates utilizing pressure transducers and staff gauges (PTs, SGs); characterizing shallow root zone salt (based on electrical conductivity, or EC), temperature and volumetric water content (VWC) responses to hydrologic loading (VWC/EC/Temperature probes); collection of soil cores to characterize deeper pore water responses to different surface hydrologic treatments; surface water quality sampling; and flow monitoring. These methods are implemented to quantify infiltration rates and their dependence upon soils, within field variance, crops and timing; develop an economic budget; and begin understanding subsurface water quality and hydrologic effects.

\section{Field Activities Required for Capturing and Applying Flood Flows}

Terranova Ranch implemented a number of activities to capture and apply flood flows onto their fields: field preparation, installation of pipeline, and equipment rental.

Field preparation was somewhat dependent upon field type. Flood flows were applied to fallow fields before the planting of summer row crops, to wine grapes, to orchards and to alfalfa. All field preparation included dividing fields into checks and installing check berms. Terranova ranch personnel surveyed the fields and located check borders to enable shallow flooding of fields to depths of $6-12$ inches throughout. For fallow fields, borders were put up around the fields and between checks to a height of about 2 $\mathrm{ft}$, using a border maker. Fiberglass risers, typically used for growing rice, were installed between checks to enable flow from check to check along the natural field gradient. Flood flows were diverted from the Kings River through a turnout at the James Bypass (Figure 3, Table 2), into the Terranova Canal and then pumped to the fields (Figure 4), where the checks were then flooded. Check berms were also put up in the wine grape fields. Each check was approximately 10 rows wide and the berms were installed between parallel vines within the rows separating the vines. Similar modifications were made to the orchard fields. These modifications were developed to allow rapid and temporary field configuration for flood flow capture that required minimal farmer investment, that minimized failure risks and could be rapidly and temporarily implemented during flood capture periods. The alfalfa field required no modifications for receiving flood flows. 
On-Farm Flood Flow Capture As a Cost Effective Method to Recharge Groundwater and Reduce Downstream Flood Risks

Agreement No. 68-9104-128

For this project, three pump stations were fabricated to draw from the Terranova Canal. These pump stations were driven by diesel engines and pumped in the range of 3,600 $5,000 \mathrm{gpm}$. Pumps for these stations were rented and installed temporarily during the operation of the project (Figure 4). At each pump, irrigators recorded flow rates daily using flow meters and recorded data into log books. We subsequently photographed field book pages for subsequent entry into an ACCESS database.

To move sufficient water throughout the system, a 24 " pipeline running north from the P30W location was installed.

\section{Daily Infiltration Rates and Seasonal Totals}

Pressure transducers (PTs) and staff gauges were installed at eight locations throughout the ranch to quantify infiltration rates (Figure 5). Water was flooded into the checks and then all outflows and inflows were ceased. PTs measured changing water levels and staff gauge readings by irrigators at the beginning and end of each flood cycle were used to calibrate the PT data. Infiltration rates (in/d) were calculated using the changes in water depth and corrected against ET (2012).

Direct and in lieu recharge were calculated from infiltration rates by correcting infiltration rates for crop ET losses.

Water applied to each site was summed to calculate seasonal totals. Integrating NRCS (1998) soils data with soils type information from local soil cores (Figure 2; KRCD 2006), we estimated minimum and maximum available water. An average minimum and maximum water capacity for soils to 100 feet was estimated through determining the available water capacity for each core based upon soil types and averaging across all cores. Using these data, we were able to estimate the depth to which applied surface waters would extend downward in the vadose zone.

\section{Water Budgets}

Flood flows were diverted onto Terranova Ranch just upstream of the James Weir (Figure 1). Flows were measured at location KR (Figure 3) with a Teledyne ISCO Acoustic Velocity Meter (AVM) on 15 minute intervals. Irrigator data for each pump included the start time for each pump cycle, to which field's water was being pumped and the percent of water to each field. We conducted QAQC within the flow database through checking data with pivot charts and queries. Data from the pumps was cross checked against location KR AVM data. We integrated the pump flow data with the field allocation data to calculate the daily flows to the different fields on Terranova Ranch. We calculated a water budget for each field utilizing the flow data with precipitation and ET data downloaded from CIMIS (2011).

\section{Water Quality, Soils Analyses and Soils Mass Budgets}

Water quality samples were collected at a number of locations in $200 \mathrm{ml}$ amber bottles, stored on ice and brought to the University of California (UC) Davis soils lab for analyses. We collected samples in amber bottles at the Kings River immediately 
upstream, within the Terranova canal, on fields at locations where flood flows were applied, and from a groundwater pump (Figure 3). Samples were stored on ice and transported to UC Davis where they were analyzed for total suspended solids as carbon (TSS-C; mg C/L) and as nitrogen (TSS-N; mg N/L), total dissolved solids (TDS; mg/L), dissolved nitrogen species as nitrogen (nitrate NO3-N, nitrite NO2-N, ammonium NH4$\mathrm{N}$, total dissolved nitrogen TDN; mg-N/L; ), dissolved phosphorus species as phosphorus (phosphate PO4-P; total dissolved phosphorus TDP; mg-P/L), dissolved organic carbon (DOC; $\mathrm{mg} / \mathrm{L}$ ) and electrical conductivity (EC as specific conductivity; milliSiemens/cm) using the methods described in Table 1 . Concurrent with sampling, we measured $\mathrm{pH}, \mathrm{EC}$, dissolved oxygen (DO; $\mathrm{mg} / \mathrm{L})$, turbidity $(\mathrm{mg} / \mathrm{L})$ and water temperature $\left({ }^{\circ} \mathrm{C}\right)$ using a YSI datasonde. We also deployed two YSI probes for two weeks at the groundwater pump (GW-Pump) and the Kings River (KR) (Figure 3).

We installed Decagon $\mathrm{ECH} 2 \mathrm{O}$ TE soil moisture probes in replicate $(\mathrm{N}=3)$ to measure changes in EC, temperature and volumetric water content. Probes were installed at depths of 6 inches and 24 inches at check locations F21CS (Field 21, southern check) and F22CS (Field 22, southern check) and also at 48" at F21CS. Probes were installed with boreholes coming into the soil at $45^{\circ}$ angles and bentonite plugs were placed every six inches to prevent preferential flow. Soil cores were collected during installation and analyzed for EC, gravimetric moisture and moisture content (Table 3).

A datalogger recorded soils data on a 15-minute interval on the hour. We estimated field capacity through observing changes in slope of moisture content data (Brady and Weil 2002). Wilting point was estimated based upon the minimum moisture content achieved during the study. Available water capacity was estimated as the difference between field capacity and wilting point and this value was compared to values provided through identification of soil types using Web Soil Survey (2010) and SoilWeb (2010).

Soil cores were collected in November 2011 after farming activities were completed at F21CS, F21CN, F22CS, F22CN, F4CN and F4CS to characterize nitrate and salt data in the root zone and below. Soil cores were collected to a depth of 120 inches (10 ft, 200 $\mathrm{cm})$, replicated on three cores at each location and then on a single core at each location data were collected to 200 inches $(16.7 \mathrm{feet} ; 500 \mathrm{~cm})$. Soil cores were collected with a Geoprobe, taken to the lab, and analyzed for EC and nitrate.

We estimated the amount of salt that could be flushed from the soils using core profile data. We assumed F4CN and F4CS represented initial conditions before flushing were to begin. We converted EC data to TDS data using the relationship developed between those constituents from this project's water quality data and estimated soil EC concentrations to TDS. We calculated mass of salts throughout the profile as the product of estimated TDS concentrations and estimated moisture content of the vadose zone soils (as field capacity). We assumed final TDS concentrations would be representative of those concentrations shown in our soil core and moisture probe data. The difference between those values was assumed as the amount of salt that could be flushed from the vadose zone. 
On-Farm Flood Flow Capture As a Cost Effective Method to Recharge Groundwater and Reduce

Downstream Flood Risks

Agreement No. 68-9104-128

\section{Economic Data Collection}

Terranova Ranch staff kept track of all costs associated with implementation of this project: field preparation and BMPs, installation and rental of equipment and infrastructure, labor, energy, project support.

\section{Results}

\section{Infiltration}

Infiltration rates measured during this study averaged $4.2 \mathrm{in} / \mathrm{d}$ for all checks (Table 4 ), ranging from an averaged low of $2.6 \mathrm{in} / \mathrm{d}$ measured at checks F22CS to an averaged high of $15.6 \mathrm{in} / \mathrm{c}$ at the adjacent F21CS. Infiltration rates differed significantly between checks due to the very high infiltration rates at Field 21 in both its north and south checks. Otherwise, fields averaged from about 2.6 to $5.7 \mathrm{in} / \mathrm{d}$.

Infiltration rates were highest during the initial period of inundation (Figure 6). During the first day of inundation, infiltration rates were often above $5 \mathrm{in} / \mathrm{d}$ ( $35 \mathrm{in} / \mathrm{d}$ max). After about 2 days of inundation, infiltration rates were in the $2-3 \mathrm{in} / \mathrm{d}$ range and these rates declined only slightly for longer periods of duration. The longest continuous duration measured during this period was 20 days at which time infiltration rates were at about $2-2.5 \mathrm{in} / \mathrm{d}$.

Infiltration rate differences were looked at within fields, between fields, between crops and between soils. Statistical differences (Statsoft 2008) in these test locations were exhibited at Field 21 and between soils. Field 21 soils ( $F x)$ were found to have statistically higher infiltration rates. All soils at the study site were primarily categorized as loamy sand or sandy loam.

Total water volumes standardized against area were calculated for each check. Three to eight feet infiltrated at the grape checks, 2 feet at the alfalfa checks and $1.5-3 \mathrm{ft}$ at the fallow fields. We estimated average available water capacity for Transect A and B soils (Figure 2 ) have a minimum of $0.08 \%$ and a max of $0.13 \%$. These available water capacities are in the range estimated for the soil series identified at the study site $(0.05$ $-0.15 \%$; NRCS 2008). Based upon these values, we estimated applied water could have extended over 100 feet into the soils for checks with the highest applied volumes (Table 5: F16CN, F22CN), assuming no preferential flows through macropores.

\section{Surface and Subsurface Water Quality and Soils}

Kings River flood flow water quality was equivalent to that of laboratory blanks with regards to nitrogen and phosphorus species, DOC and TDS concentrations (Figure 7). Applied groundwater had TDN concentrations averaging $45 \mathrm{mg} / \mathrm{L}$ with ammonium and nitrate concentrations similar, TDP concentrations at about $0.5 \mathrm{mg} / \mathrm{L}$ with $40 \%$ as phosphate, DOC concentrations averaging $15 \mathrm{mg} / \mathrm{L}$ and TDS concentrations averaging $900 \mathrm{mg} / \mathrm{L}$. When flood waters were used to irrigate, the resulting standing water on the fields had elevated TDS, phosphate, TDP, DOC and TDS concentrations, presumably from constituents leaching from the soils to the water column. YSI data showed EC in 
On-Farm Flood Flow Capture As a Cost Effective Method to Recharge Groundwater and Reduce Downstream Flood Risks

Agreement No. 68-9104-128

pumped groundwater to be two orders of magnitude higher than river water at around $1.5 \mathrm{mS} / \mathrm{cm}$ (Figure 8).

Recharge practices occurred for about two weeks starting in late January into February and from mid-March through early June. During these periods, VWC reached a high of about $0.3 \mathrm{~m}^{3} / \mathrm{m}^{3}$ at depths of 6 and 24 " below the surface and remained elevated while standing water was on the fields (Figure 9). Once flooding had ceased, VWC dropped over the next few days to the field capacity. While VWC was above field capacity, water was migrating downward through the soil profile.

Using moisture probe VWC trends we estimated field capacity at $18 \%$ for Field 21 (Figure 10) and at $25 \%$ for Field 22 (Figure 11). VWC determined from moisture probes correlated well with gravimetric results from soils collected during probe installations. Differences in field capacity between fields likely results from slight different soils and from differences between moisture probes (Table 4). We estimated wilting point from Field 22 at about 13.5\% (Figure 11). These data suggest the available water capacity of the Cajon loamy coarse sand, saline alkali soils (Cb) in Field 22 is about $4-5 \%$, consistent with NRCS soils data predicting a range of $6-10 \%$ (NRCS 1998).

The hydrologic treatment (flood capture and recharge) used in $\mathrm{F} 22 \mathrm{CN}$ greatly decreased root zone salt levels. EC decreased from about $0.8 \mathrm{ds} / \mathrm{m}$ to $0.1 \mathrm{ds} / \mathrm{m}$ at a soil depth of 6 inches and from 0.65 to $<0.1 \mathrm{ds} / \mathrm{m}$ at a soil depth of 24 inches (Figure 10). Greatest decreases occurred during the first $3-4$ weeks of flooding, mid-January into February. With each flood event, EC levels changed in response to VWC changes, slightly higher with higher VWC values and decreasing with decreasing VWC values. This trend suggests applied surface waters remobilized salts in the soil column.

Groundwater irrigation returned during the summer. EC increased to about $0.25-0.3$ $\mathrm{dS} / \mathrm{m}$ in the top 6 inches and to $0.15-0.2$ at 24 inches. Late season flushing with groundwater pumping resulted in transient elevated EC levels which disappeared as VWC decreased below field capacity. These data suggest higher salinity irrigation water passed more readily through the water column while pores retained low EC waters.

Field 21 study checks received about $40 \%$ of the applied surface water volume as did Field 22 study checks (Table 5) and did not receive flood flows until late March. EC levels were about $0.3 \mathrm{dS} / \mathrm{m}$ at a 6" soil depth, $0.8 \mathrm{dS} / \mathrm{m}$ at 24 " soil depth and 0.55 $\mathrm{dS} / \mathrm{m}$ at $48^{\prime \prime}$ soil depth (Figure 11 ). Flood flow applications reduced EC levels to about $0.1 \mathrm{dS} / \mathrm{m}$ at a 6" depth but were insufficient to decrease EC levels much below 0.3 $\mathrm{dS} / \mathrm{m}$ in deeper soils. With summer irrigation, EC levels increased to about $80 \%$ of initial conditions.

From soil core data collected in November, we determined nitrate distribution differences between Fields 21,22 and 4 . Figure 12 shows nitrate mass at $0-40$ inches $(0-100 \mathrm{~cm})$ and deeper at $40-200$ inches $(100-500 \mathrm{~cm})$. Figure 13 presents EC levels throughout the soil profile, corresponding nitrate concentrations in the soils, and the relation between EC and nitrate for a northern and southern check location. In Field 4, nitrate and EC concentrations were elevated throughout the soil profile. For the 
On-Farm Flood Flow Capture As a Cost Effective Method to Recharge Groundwater and Reduce Downstream Flood Risks

Agreement No. 68-9104-128

checks in Field 21 and 22, nitrate and EC had generally been flushed from the soil profile with the hydrologic treatments used in those fields: Field 21, over irrigation winter through early summer; and Field 22, direct recharge in the winter with over irrigation into the summer. The relationship between $\mathrm{EC}$ and nitrate concentrations was significant and well correlated $(r=0.85, p<<0.01)$. Field 21 and 22 nitrate concentrations were significantly different $(p<0.05)$ than those measured in Field 4.

Nitrate mass (Nitrate- $\mathrm{N} \mathrm{g} / \mathrm{m}^{2}$ ) in the soil cores for depths of $0-40$ inches and $40-120$ inches are shown in Figure 12. Feet of water applied is also shown for each plot. F21CN, F21CS and F22CS have a total of $3-15 \mathrm{NO}-\mathrm{N} \mathrm{g} / \mathrm{m}^{2}$. Check F22CN has a total of $100 \mathrm{NO}_{3}-\mathrm{N} \mathrm{g} / \mathrm{m}^{2}$. The amount of $\mathrm{NO}_{3}-\mathrm{N}$ found in Field 4 is about one order of magnitude greater than that found in all the other checks except for $\mathrm{F} 22 \mathrm{CN}$. On average, nitrate mass found in the soil cores in Fields 21 and 22 is less than $15 \%$ the mass found in Field 4 soil cores. On average the soil profile in Fields 21 and $22(0-120$ inches) has about $215 \mathrm{NO}_{3}-\mathrm{N} \mathrm{g} / \mathrm{m}^{2}$ less nitrate than the soil profile found in Fields 4 .

\section{Surface Water Budget}

From January into early February and from late March through early July (Figure 14) flows diverted from the Kings River ranged from $2-22 \mathrm{cfs}$. 3,116 ac- $\mathrm{ft}$ was diverted onto Terranova Ranch. From April through mid-July, almost 2,000 ac-ft were applied to the ranch (Table 6). Wine grapes received the most water during April and May, with the greatest applications on Fields 16 and 22 . In total, the wine grapes received about 900 acre-ft over 7 approximately 70 -ac fields, corresponding to nearly 2 feet applied on average to each field. Fields 16 and 22 received about $3 \mathrm{ft}$ during that period. Water application to the wine grapes dropped to about half for the remaining period from June to mid-July.

During the water application period, pistachios and alfalfa fields received water volume similar to those applied to wine grapes. Fallow fields, onions and tomatoes received water into May, at which time fields were prepped and planted.

\section{Recharge v Irrigation}

Table 7 presents water budgets for the different fields which received flood flows for our farm-scale demonstration of this technology. Highlighted fields received water with a focus on direct recharge. For those fields, $50-75 \%$ of total applied water went towards direct recharge. For the project as a whole, about $30 \%$ of the applied water went towards direct recharge and $70 \%$ went towards in lieu recharge.

Table 8 shows monthly water budget for key crops receiving flood flows, showing precipitation, crop evapotranspiration (ETc), flood flows, and the balance. Most flood flows were diverted from April to July. For the wine grapes, flood flows which averaged 8 inches per field for all the fields exceeded crop ETc demands through May. By June, flood flows were insufficient to meet ETc demands. Pistachio orchards received about 4 -8 inches per month of flood flows from April through June. Only April applications exceeded crop ETc demands. Alfalfa fields were also big consumers of flood flows, receiving similar hydrologic loading rates as the pistachio and wine grape fields. 
On-Farm Flood Flow Capture As a Cost Effective Method to Recharge Groundwater and Reduce Downstream Flood Risks

Agreement No. 68-9104-128

However, flood flows diverted to alfalfa fields were only sufficient to meet monthly ETc demands. ETc demands for wine grapes and pistachios were lower than alfalfa in May.

Overall, ETc demand is very low in the winter and through early spring (Figure 15, Table 8). ETc water demand increases in March for alfalfa but not till May for vineyards and pistachios, which were dormant during the winter. Thus, little water applied on crops such as pistachios and wine grapes was loss the ETc until May.

\section{Economics}

Costs were tracked for this project. For the project year, farm costs for labor, land preparation, diesel, improvements and fuel were about $\$ 113,000$ and when standardized against the volume diverted was $\$ 38 /$ ac-foot (Table 9 ).

We also estimated these costs for a 25-year period and broke down costs based upon expected one-time costs and recurring costs. We added fixed costs of $20 \%$ (MWH 2004). Water recharged during that 25 -year period was assumed to be of equivalent level as during this project year. Based upon that assumption, flood capture costs were $\$ 35 / a c-f t$ with most those costs reoccurring during each period flood flow capture is occurring.

\section{Discussion}

\section{Soil Series and Predicting Infiltration on Agricultural Lands}

Soil series Fx had the highest and statistically significant $(p<0.05)$ measured infiltration rates for all soils. These infiltration rates averaged $6.3 \mathrm{in} / \mathrm{d}(16 \mathrm{~cm} / \mathrm{d})$ and are much higher than rates expected for these soils. These soils were found in Field 21, where infiltration rates up to $24 \mathrm{in} / \mathrm{d}(61 \mathrm{~cm} / \mathrm{d})$ were measured and were statistically different than infiltration rates measured at any other field location.

The soils on which infiltration rates were measured were fine sandy loams ( $\mathrm{Fu}, \mathrm{Fx}$ ), sandy loam ( $T \mathrm{~T})$, loamy coarse sand $(\mathrm{Cb})$ and fine sandy loam/clay loam (Pt). Infiltration is expected to be very limited for all these soils (Table 10), primarily because of a cemented duripan restricting infiltration rates $2-3$ feet down $(60-90 \mathrm{~cm})$ in the soil layer. $K_{\text {sat }}$ for these restrictive layers range from $0-1 \mathrm{~cm} / \mathrm{d}$.

The infiltration rates measured in this study were higher than would be expected for these soil series. These infiltration rates did not differ significantly between crop types (alfalfa, wine grapes, fallow). This result suggests cultural practices (e.g. deep ripping) used for enhancing crop production in these fields have benefitted infiltration rates.

\section{Saturated zone hydrologic and salinity budget and implications on groundwater management}

Overdraft has been occurring for years in the Kings Basin. The Kings River Integrated Groundwater and Surface water Model (IGSM) calculates all sources of water to the Kings Basin including deep percolation from the east and south and estimates overdraft in the Kings Basin at about 160,000 ac-ft annually, with about 100,000 ac-ft overdrafted 
On-Farm Flood Flow Capture As a Cost Effective Method to Recharge Groundwater and Reduce Downstream Flood Risks

Agreement No. 68-9104-128

from the Lower Kings Basin and 60,000 overdrafted from the Upper Kings Basin (WRIME, 2007). Chronic and severe overdraft has resulted in the groundwater table about 200 feet below ground surface at Terranova Ranch.

The greatly subsided groundwater table is a problem for farms in this region of California as groundwater is the primary irrigation source. The deep water table and the groundwater quality pose challenges for irrigation. For instance, pumped groundwater (2007 - 2009) was of much lower quality than diverted Kings River flood flows during 2011. Mean nitrate levels were about $3 \mathrm{mg} \mathrm{NO}-\mathrm{N} / \mathrm{L}$, ranging up to $11 \mathrm{mg}$ $\mathrm{NO}_{3}-\mathrm{N} / \mathrm{L}$ and one to two orders of magnitude greater than measured flood flow concentrations. Mean EC levels were about $1 \mathrm{dS} / \mathrm{m}$ (Table 11), ranging up to $3 \mathrm{dS} / \mathrm{m}$ and typically about 50 times higher than flood flows. EC levels were similar to those found in the shallow root zone at depths of 24 and 48 inches (Fields 21 and 22) when this project initiated (Figure 10, Figure 11). EC levels above $2 \mathrm{dS} / \mathrm{m}$ stress yields for sensitive and moderately sensitive crops (Ayers and Westcott 1994), a number of which are grown on the Terranova Ranch (e.g., grapes, almonds, alfalfa).

Thus, these data also are consistent with the idea that groundwater quality, particularly salinity, pose long-term problems (Schoups et al, 2005). Salts and nitrate are accumulating in groundwater in many regions of the Central Valley (Larry Walker and Associates, et al., 2010; DWR 2003). Kings River Basin salinity generally increases from the eastern foothills to the west, reflecting 1) low salinity and TDS of recharge waters sources (e.g., Kings River, San Joaquin River, smaller watersheds in the upper Kings basin); and 2) groundwater picking up dissolved solids as the water moves west with higher bicarbonate and calcium bicarbonate concentrations (WRIME, 2007b). WRIME (2007b) consolidated public well data and found salinity generally higher in the Kings Basin regions west of Highway 99, near or above the agricultural MCL of $450 \mathrm{mg} / \mathrm{L}$ (no effect) (Ayers and Westcott, 1994). These values however are likely below the range Ayers and Westcott (1994) identify as requiring slight to moderate restrictions on use, $450-2000 \mathrm{mg} / \mathrm{L}$.

Figure 16 presents a conceptual model of recharge utilizing flood flows and its impact on water quality throughout the profile. Data trends in the root zone, shallow unsaturated zone (to 15 feet), and groundwater are based upon data collected for this project. The model presents 1) temporal changes in water and constituent movement through the soil profile during a relatively short time period for flood flow capture program during the first year and then 2 ) longer term changes with steady state conditions at the end of subsequent years flood flows are captured and allowed to infiltrate. The conceptual model temporally and spatially extrapolates based upon a number of assumptions:

- Tightly bound micropore waters, as defined by the wilting point, exchange constituents with other pore waters primarily through diffusion;

- Less tightly bound water, as defined by water retained between the wilting point and field capacity, can either exchange constituents through diffusion or can be displaced through propagation of a wave; 
- Water within the soils above field capacity primarily exchange through advection and move relatively rapidly downward;

- Within the root zone influence, water volume in the pore spaces can drop below field capacity through evapotranspiration and evaporation; and

- Water below the root zone influence is generally near field capacity.

- Salinity levels in the unsaturated zone are similar to values measured with the geoprobe (Figure 13).

In addition to these assumptions, we assume based upon our data (Table 5) that during a flood flow capture season, a 60 foot depth of influence for that water would be reasonable. This model illustrates water quality and hydrologic trends from the application of flood flows but does not consider other externalities such as groundwater pumping or lateral groundwater flow. The model also assumes farm practices to minimize the accumulation of salts in the root zone are implemented.

The conceptual model shows root zone EC concentrations are in relative equilibrium with groundwater, the irrigation source. High quality, low EC flood flows are applied $(T=1.1)$ and water content in the root zone is raised above field capacity. Throughout the Kings Basin, salinity has generally been about an order of magnitude lower in surface waters than in groundwater (WRIME, 2007b) and this difference was greater with the flood flows measured in this study. This flood waters reduces the EC content of micropore water through diffusion and by displacing less tightly held waters. With continued application of flood flows $(T=1.2,1.3)$, EC concentrations in the root zone continue to decrease and the higher constituent concentrations move down as well. This movement is through both advective transport and through displacement of water in pore spaces. Once flood flows stopped $(T=1.4)$, advective flow stops in the upper root zone but the front continues to move downward as moisture content in deeper soils is raised above field capacity. Eventually, the water is dispersed enough such that water movement essentially stops and salts have been forced downward $(T=1.6)$. At the end of the first water event year $(T=1 f)$, the constituent front has moved down about 60 feet and become more dispersed.

During subsequent years, soil pores continue to be flushed of salts though dispersion, advection and displacement. Lower salinity water and low constituent concentrations push down the profile and the high salinity front continues to migrate down the profile. Essentially, salinity migrates downward through diffusion, advection and displacement, moving into the groundwater table, causing groundwater to increase salinity concentrations. The temporal salinity trend continues until salts have been flushed from the unsaturated zone and at that point salinity levels within the groundwater table begin a long-term trend of decreasing.

From the conceptual model, we have a number of expectations with regard to salinity management and implications from this technology. First, legacy salinity will migrate from the unsaturated zone into the groundwater table. Salinity levels in shallow unsaturated zone at Field 4 was in the range of $0.5-3 \mathrm{dS} / \mathrm{m}$. This field represented an initial condition for flushing as no flood flows were applied (Figure 13). Salinity levels 
On-Farm Flood Flow Capture As a Cost Effective Method to Recharge Groundwater and Reduce Downstream Flood Risks

Agreement No. 68-9104-128

trend down $200-400 \mathrm{~cm}$ and suggest the deeper unsaturated zone may have lower salinity as has been assumed for the conceptual model (Figure 16).

We have developed a mass budget based upon our conceptual model from the period of $T=1_{i}$ to $T=6_{f}$, representing the flushing of the salts from the unsaturated zone (Figure 16). Approximately $10 \mathrm{~kg} / \mathrm{m}^{2}$ salts are flushed from the pore spaces under this scenario into the groundwater table (Table 12). The model predicts EC and TDS levels rise during the period of flushing but in reality salinity variance is very high at Terranova Ranch and approximately $1 / 3$ of the groundwater samples measured had higher salinity levels than the average salinity modeled throughout the unsaturated zone.

Groundwater being pumped at Terranova Ranch is currently borderline for sensitive crops. About 1/3 of groundwater samples collected from wells between $2007-2009$ had salinity levels that could affect sensitive crops. Based upon our data, we expect average groundwater salinity concentrations to increase when the salinity bulge is flushed into groundwater and then to subsequently decrease. The amount of increase will depend upon the volume of water flushed and the depth of groundwater.

According to WRIME (2007b), groundwater quality is relatively high in the upper 400 feet on the western Kings Basin Area. If only the upper 400 feet is affected, mass budget calculations estimate salinity will increase by an average of about $0.3 \mathrm{dS} / \mathrm{cm}$ and TDS by about $300 \mathrm{mg} / \mathrm{L}$ in well-mixed pumped groundwater.

Importantly, the model also predicts groundwater salinity will improve over time as has occurred in areas in which recharge with high quality surface waters is occurring in the Kings Basin (WRIME 2007b). We estimate approximately $12 \mathrm{~m}^{3} / \mathrm{m}^{2}$ of recharge water will need to be displaced in the unsaturated zone to displace the salts currently in that zone. An equivalent water volume is estimated as needed to return underlying groundwater to their current conditions. Greater volumes of recharge water would be expected to further decrease groundwater salinity.

\section{Considerations for Regional and Local Implementation Logistics}

On-farm flood flow capture represents a new approach and paradigm for the farming community: actively integrating flood flow capture and recharge into farm management. For farmers' and water managers' in the Kings Basin, the primary motivator for capturing flood flows will be to address chronic and severe groundwater overdraft.

With about $0.16 \mathrm{M}$ ac-ft overdrafted annually (WRIME, 2007), substantial efforts to address the overdraft will require substantial acreage. Median flood flows past the James Bypass during years in which they occur are about 1500 CFS. Capturing those flows over a 3 month period would enable capture of about 280,000 ac-ft, exceeding the annual overdraft. Soils can be classified in soil Hydrologic Groups A through D, depending upon their infiltration characteristics. Group A soils are primarily sands or gravelly sands and have high infiltration rates. Group B soils have moderate fine to course texture. Group C soils have moderately fine to fine texture. Group D soils consist chiefly of clays. These soils range from high to very slow infiltration rates and 
On-Farm Flood Flow Capture As a Cost Effective Method to Recharge Groundwater and Reduce Downstream Flood Risks

Agreement No. 68-9104-128

depending upon the soil characteristics, great differences in acreage would be needed to capture median flows. A few hundred to 1,000 acres are needed for Group A soils whereas about 25X that many are needed for Group D soils (Table 13). Clearly, effective implementation of this program requires appropriate soils.

At Terranova, soils were generally classified with Hydrologic Groups C, somewhat poorly drained, primarily because of a restrictive layer at $2-3$ foot depth. Expected infiltration rates were predicted to be low because of very saturated hydraulic conductivity at the restrictive layer (Table 14). These predicted rates were much lower than those measured at these same fields (Table 5). Mean infiltration rates measured throughout the study were $4.2 \mathrm{in} / \mathrm{d}$ (Table 4) and rates measured after long-term inundation decreased asymptotically to about $2-2.5$ in/d (Figure 6). Presumably, deep ripping to prepare fields for crops fractured the restrictive layer and resulted in much higher infiltration rates than predicted from the soil series information.

From the infiltration data, we are able to estimate acreage needed for each CFS captured. At about $2.5 \mathrm{in} / \mathrm{d}$ infiltration rate, approximately 10 acres are required to capture 1 CFS (Figure 17). For the infiltration rates measured at Terranova, the ratio ranged from about $4-16$ acres required for each CFS captured. When scaling those numbers up to median flows past the James Bypass, we calculate between 6,500 and 24,000 acres would be needed to capture those flows for fields with hydrologic characteristics similar to those at Terranova Ranch.

Aside from meeting the technical requirements for implementing this program, a number of regional and local logistical issues will need to be addressed (Table 14). From a regional perspective, these are not trivial and include addressing issues of conveyance, system O\&M, sustainable cost structures and integration with regional water managers. At the farm-scale, the logistics of on-farm flood flow capture introduces complexity: integrating flood capture with agronomic plans and practices to create a complementary dual use program; creating hydrologic systems to support the different operational components of this program (i.e., direct recharge, in lieu recharge, flow buffering); creating a sustainable cost structure that might include irrigation savings, cost reimbursement from partnering organizations, and easements; longer term and rapidly deployed infrastructure to allow rapid and temporary response to flood flow events; and personnel management. We expect central premises to these plans will be farm operational flexibility, integration of agronomic and flood capture management practices and cropping practices and regional coordination.

\section{Costs and Sustainability}

Flood flows diverted to Terranova Ranch under this project were used for both direct recharge and in lieu recharge. For fields in which recharge efforts were most active, Fields 16,22 and 28 (wine grapes), about $50 \%$ of the captured flood flows applied to those fields went towards direct recharge and the remainder went towards in lieu recharge. For the period in which flood flows were applied to fields, ET demands were highest from late May into July (Figure 15). Prior to that period, in lieu recharge primarily replenished the root zone. Once the growing season began, in lieu recharge 
primarily met ET demand. For the project as a whole, about $70 \%$ of the flood flows captured went toward in lieu recharge and about 30\% went towards direct recharge.

Capturing flood flows on-farm compared favorably to other methods for direct and in lieu recharge, costing \$36/ac-ft when projected over a 25-year (Table 9). These costs are only slightly lower than the costs estimated for during the period of this project because the majority of costs are reoccurring and not one-time. Potentially, these costs could have been lower on an ac-ft basis. Irrigators applied flood waters to the study checks more optimally to ensure the project goals would be achieved. If flood waters were applied throughout the study area (Figure 3) similarly, 8 - 10 times more water could potentially have been accommodated, likely decreasing per ac-ft costs. Nonetheless, the costs for this project were comparably low (MWH, 2004; James Irrigation District 2010). MWH (2004) estimated per acre-foot recharge costs using engineering basin system for in lieu and direct recharge to range from $5-97 \$ / a c-f t$, with a median costs of $51 \$ /$ ac-ft. James Irrigation District (2010) charges consumers $\$ 88-91 /$ ac-ft for irrigation purposes, relying primarily on groundwater.

This approach provides a number of clear economic benefits. Because some captured flood flows are utilized for in lieu recharge, irrigation costs are avoided from pumping groundwater. Pumping groundwater for irrigation is estimated to costs Terranova Ranch about $\$ 95 /$ ac-ft but may be as high as $\$ 120 / a c-f t$ (Cameron, personal communication), and farmers pay the nearby James Irrigation District $\$ 88-91 /$ ac-ft (James Irrigation District 2010). Figure 18 shows the combined cost to irrigate and capture flood flow for recharge on an acre-foot basis. When flood flows are captured but not utilized for in lieu recharge purposes, the cost to capture $1 \mathrm{ac}-\mathrm{ft}$ and to irrigate with 1 ac-ft are $\$ 131 / \mathrm{ac}-\mathrm{ft}$; the cost of flood flow capture ( $\$ 36 / \mathrm{ac}-\mathrm{ft}$ ) plus the cost of groundwater pumping (\$95/ac- $\mathrm{ft}$ ). These costs represent the cost of recharging and extracting the necessary water for sustainable irrigation practices. When $100 \%$ flood flows are used for in lieu recharge, total cost drops to only flood flow capture costs as no groundwater is needed. For this project, utilizing $25 \%$ of captured flood flows for in lieu recharge corresponds to the point Terranova begins to save irrigation costs. When $25 \%$ or more of the captured flood flows are utilized for irrigation, irrigation costs drop. These avoided costs associated with irrigation form a basis for investing in and saving with groundwater recharge practices.

Additionally, these practices provide avoided flood damage costs. Since 1983, three years have experienced flood damage downstream of Terranova Ranch along the Kings River and the San Joaquin Rivers. The floods in 1983, 1995 and 1997 have caused \$1.2 billion (2012 dollars) in damage. If 500 CFS could have been diverted reliably from the Kings River at the James Bypass during that period, nearly $1 \mathrm{M}$ ac-ft would have been diverted at the Bypass and the Kings River would have stayed below design flood flow rates. Under this scenario, the diverted $1 \mathrm{M}$ ac-ft potentially would have avoided damages of $\$ 1.2 \mathrm{~B}$ at about $\$ 1,250$ in avoided damages per ac- $\mathrm{ft}$. 
On-Farm Flood Flow Capture As a Cost Effective Method to Recharge Groundwater and Reduce

Downstream Flood Risks

Agreement No. 68-9104-128

\section{Conclusion}

In check studies, we measured average infiltration rates of $4.2 \mathrm{in} / \mathrm{d}$ for all fields and noted infiltration rates declined over time to an asymptote of about $2-2.5 \mathrm{in} / \mathrm{d}$. Rates did not differ significantly between the different crops and soils tested, but were found to be about an order of magnitude higher in one field. At $2.5 \mathrm{in} / \mathrm{d}$ infiltration, 100 acres are required to infiltrate 10 CFS of captured flood flows.

Water quality of applied flood flows from the Kings River had concentrations of COC (i.e. nitrate, EC, phosphate, ammonium, TDS) about one order of magnitude or more lower than for pumped groundwater at Terranova Ranch and similarly for a broader survey of groundwater in the region. Applied flood flows flushed the root zone and upper vadose zone of nitrate and salts, leading to much lower $\mathrm{EC}$ and $\mathrm{NO}_{3}$ concentrations to a depth of 200 inches when compared to fields in which more limited flood flows were applied or for which drip irrigation was the sole water source.

In demonstrating this technology on the farm, approximately 3,100 ac-ft was diverted onto the farm, primarily from April through mid-July for both in lieu and direct recharge. Substantial flood flow volumes were applied to alfalfa, wine grapes and pistachio fields. A subset of those fields, primarily wine grapes and pistachios, were used for direct recharge purposes, and for those fields about $50-75 \%$ of water applied was calculated going to direct recharge. Prior to May, nearly all applied water was calculated as going to direct recharge. These volumes would have been less in a field crop like alfalfa, which has higher winter and early spring ETc rates. These findings show the technical feasibility of this approach.

Costs were tracked for this project and costs to capture flood flows for direct and in lieu recharge were comparably low to other nearby recharge operations. The high capacity also suggests significant community cost savings can be achieved through flood avoidance.

Two important issues need further consideration. First, these practices are likely to leach legacy salts and nitrates from the unsaturated zone into groundwater. We develop a conceptual model of EC movement through the unsaturated zone and estimated through mass balance calculations (with assumptions detailed in the manuscript) that approximately $11 \mathrm{~kg} / \mathrm{m}^{2}$ of salts will be flushed into the groundwater through displacing $12 \mathrm{~m}^{3} / \mathrm{m}^{2}$ of unsaturated zone pore water. This flux would increase groundwater salinity but an equivalent amount of water added subsequently is predicted as needed to return to current groundwater salinity levels. All subsequent flood flow capture and recharge is expected to further decrease groundwater salinity levels.

Second, the project identified important farm-scale logistical issues including irrigator training to understand different management agendas when applying flood flow for direct recharge as opposed to irrigation; developing cropping plans to integrate farming and recharge activities; upgrading conveyance to transport higher flow rates; and quantifying results. Regional logistical issues also exist related to conveyance, integration with agricultural management, economics, required acreage and O\&M. 
On-Farm Flood Flow Capture As a Cost Effective Method to Recharge Groundwater and Reduce Downstream Flood Risks

Agreement No. 68-9104-128

\section{Acknowledgements}

This project was funded through a NRCS CIG grant with significant matching funds provided by Terranova Ranch. We acknowledge the staff of Terranova Ranch for their efforts in implementing management practices, taking field notes on those practices, documenting costs, and providing support of the research. We also appreciate the efforts of Rick Hoelzel and Eric Osterling of Kings River Conservation District, Steve Haugen of Kings River Water Association, Dave Krietemeyer and Chris Hartley of the NRCS and John Mallyon of the James Irrigation District who supported this project in many ways: facilitation and coordination, technical assistance and outreach. We appreciate the support of UC Davis scientific staff in providing expertise on coring and laboratory methods and supporting collection of those data. Finally, we acknowledge the modeling groups, the Program for Climate Model Diagnosis and Intercomparison (PCMDI) and the WCRP's Working Group on Coupled Modelling (WGCM) for their roles in making available the WCRP CMIP3 multi-model dataset. Support of this dataset is provided by the Office of Science, U.S. Department of Energy.

\section{References}

Ayers, R.S. and D.W. Westcot. 1994. Water quality for agriculture. FAO IRRIGATION AND DRAINAGE PAPER 29 Rev. 1. M-56. ISBN 92-5-102263-1

Brady, N.C. and R.R. Weil. 2002. The Nature and Properties of Soils, 13th Edition. Prentice Hall. Upper Saddle River, NJ.CIMIS. Westlands Station 105, Westlands, $1 / 1 / 2011-12 / 7 / 2011$

Doane, T.A. and W. R. Horwath. 2003. Spectrophotometric Determination of Nitrate with a Single Reagent. Analytical Letters: Anal Lett 36,: 2713-2722

DWR. 2003. California's Groundwater. Bulletin 118, 2003 update. State of California, The Resources Agency Department of Water Resources.

KRCD. 2000. Feasibility Study Report. Preliminary Design and Estimate of Costs for Two Potential Groundwater Recharge Sites Within the McMullin Recharge Project Area. Kings River Conservation District. April 2000.

KRCD. 2006. McMullin Recharge Feasibility Study. 2006. Proposition 13 Grant No F7708 with DWR.

Larry Walker and Associates, Luhdorff \& Scalmanini Consulting Engineers, Systech Water Resources, Inc., Newfields Agricultural and Environmental Resources LLC, Department of Land Air and Water Resources UC Davis. 2010. CV-SALTS. Salt and Nitrate Sources Pilot Implementation Study Report. February, 2010.

Megdal, S.B. et al. 2009. CAST Issue Paper No. 44. Water, People and the Future: Water availability for Agriculture in the United States; California Water Plan 2009

Murphy, J. and Riley, J.P. (1962). A modified single solution method for the determination of phosphate in natural waters. Analytica Chimica. Acta 27, 31-36. 
On-Farm Flood Flow Capture As a Cost Effective Method to Recharge Groundwater and Reduce Downstream Flood Risks

Agreement No. 68-9104-128

James Irrigation District. 2010. Water Management Plan. Prepared for Bureau of Reclamation. Prepared for Bureau of Reclamation Mid-Pacific Region

Langridge, R., A. Fisher, A. Racz, B. Daniels, K. Rudestam, and B. Hihara. 2012. Climate Change and Water Supply Security: Reconfiguring Groundwater Management to Reduce Drought Vulnerability. California Energy Commission. Publication Number: CEC-5002012-017.

Maurer, E. P., L. Brekke, T. Pruitt, and P. B. Duffy (2007), 'Fine-resolution climate projections enhance regional climate change impact studies', Eos Trans. AGU, 88(47), 504.

Maurer, E.P., H.G. Hidalgo, T. Das, M.D. Dettinger, and D.R. Cayan, 2010, 'The utility of daily large-scale climate data in the assessment of climate change impacts on daily streamflow in California', Hydrology and Earth System Sciences, 14, 1125-1138, doi:10.5194/hess-14-1125-2010.

MWH. 2004. Dry Creek Recycled Water, Groundwater Recharge Feasibility Study. Prepared for City of Roseville. Produced by MWH, Inc., Job number 1511098. Contributing agencies: City of Roseville Department of Utilities, Sacramento Groundwater Authority, and California Department of Water Resources. June 2004.

NRCS. 1998. Soil Quality Information Sheet, Soil Quality Resource Concerns: Available Water Capacity. January 1998. http://soils.usda.gov/sqi/publications/files/avwater.pdf

Reclamation, 2011. 'West-Wide Climate Risk Assessments: Bias-Corrected and Spatially Downscaled Surface Water Projections', Technical Memorandum No. 86-68210-2011-01, prepared by the U.S. Department of the Interior, Bureau of Reclamation, Technical Services Center, Denver, Colorado. 138pp.

Reclamation. 2012. Performance Work Statement, Sacramento-San Joaquin Basins Study Climate Change Impact Assessment and Adaptation Planning for Sacramento, San Joaquin and Tulare Lake Basins. U.S. Bureau of Reclamation. July 23, 2012

Schoups,G., J.W. Hopmans, C.A. Young, J.A. Vrugt, W.W. Wallender, K.K. Tanji and S. Panday. 2005. Sustainability of irrigated agriculture in the San Joaquin Valley, California. PNAS 102(43): 15352-15356. www.pnas.org/cgi/doi/10.1073/pnas.0507723102

Soilweb (2008). Interface to USDA-NCSS SSURGO and STATSGO Soil Survey Products. Source data changes with map scale. Copyright Ca Soil Resource Lab, 2008.

StatSoft, Inc. (2008). STATISTICA (data analysis software system), version 8.0. www.statsoft.com.

Tetra Tech (2011): K. Sayenko, W. B. Mills, C. Lew, L. Chen, R. Kurkjian and S. B. Roy, R. Wright, W. Stracker, and V. Mintchev. Task D: Identification and Analysis of Potential Measures to Address Climate Change Impacts on the Los Angeles Aqueduct (LAA). Draft Final Technical Report. Prepared for LADWP.

Thorne, J., R. Boynton, L. Flint, A. Flint, and Thuy-N'goc Le (University of California, Davis and U.S. Geological Survey). 2012. Development and Application of Downscaled 
Hydroclimatic Predictor Variables for Use in Climate Vulnerability and Assessment Studies. California Energy Commission. Publication number: CEC-500-2012-010.

Valderrama JC (1981) The simultaneous analysis of total nitrogen and total phosphorus in natural waters. Marine Chemistry 10: 109-122

Web Soil Survey. 2010. Soil Survey Staff, Natural Resources Conservation Service, United States Department of Agriculture. Available online at http://websoilsurvey.nrcs.usda.gov/. Accessed November 2010 through June 2011.

WRIME. 2006. Memorandum: Kings Basin Conjunctive Use Feasibility Analysis. Prepared for Kings River Conservation District and Upper Kings Water Forum by Water Resources \& Information Management Engineering, Inc. December 2006. http://www.krcd.org/water/ukbirwma/docs rept.html

WRIME. 2007. Kings Basin Integrated Groundwater and Surface water Model (Kings IGSM). Model Development and Calibration. Prepared for Upper Kings Basin Water Forum, Kings River Conservation District, and City of Fresno in Coordination with California Department of Water Resources by Water Resources \& Information Management Engineering, Inc. November 2007. http://www.krcd.org/water/ukbirwma/docs rept.html

WRIME. 2007b. Technical Memo: Water Quality Standards, Conditions, and Constraints. Prepared for: Upper Kings Basin Water Forum and Kings River Conservation District In Coordination with California Department of Water Resources 
On-Farm Flood Flow Capture As a Cost Effective Method to Recharge Groundwater and Reduce Downstream Flood Risks

Agreement No. 68-9104-128

\section{Figures}




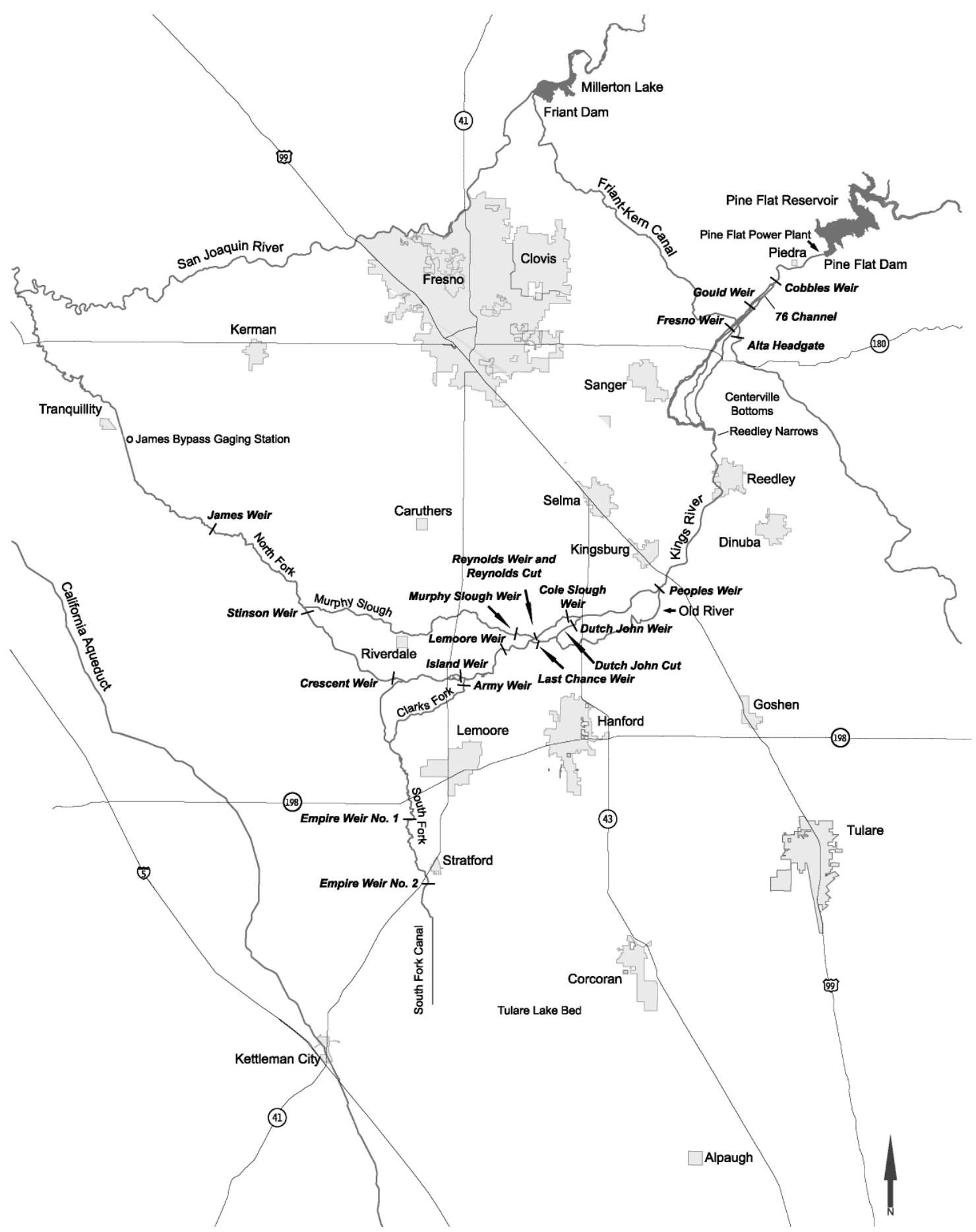

Figure 1. Hydrologic Features of the Kings River.

The Kings River flow from the Sierra Nevada west across the San Joaquin River and then north to the Mendota Pool where it meets the San Joaquin River. Pine Flat Dam is managed by KRWA and the Army Corps to control floods and to allocate water for irrigation. 


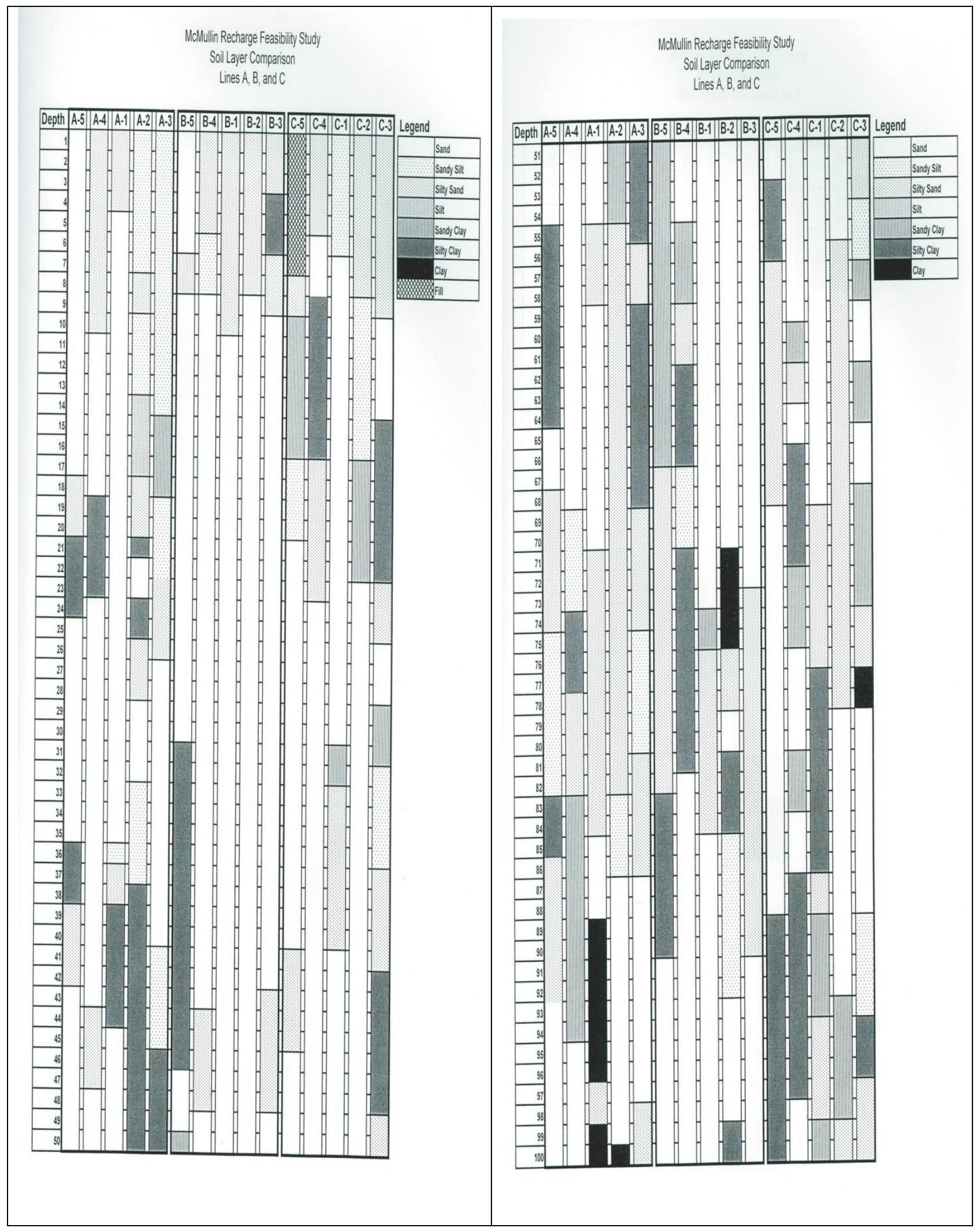

Figure 2. Boring Log Summary for Recharge Feasibility Study, 0 - $100 \mathrm{ft}$.

Boring logs were taken from transects in the region of the study (KRCD 2006). 


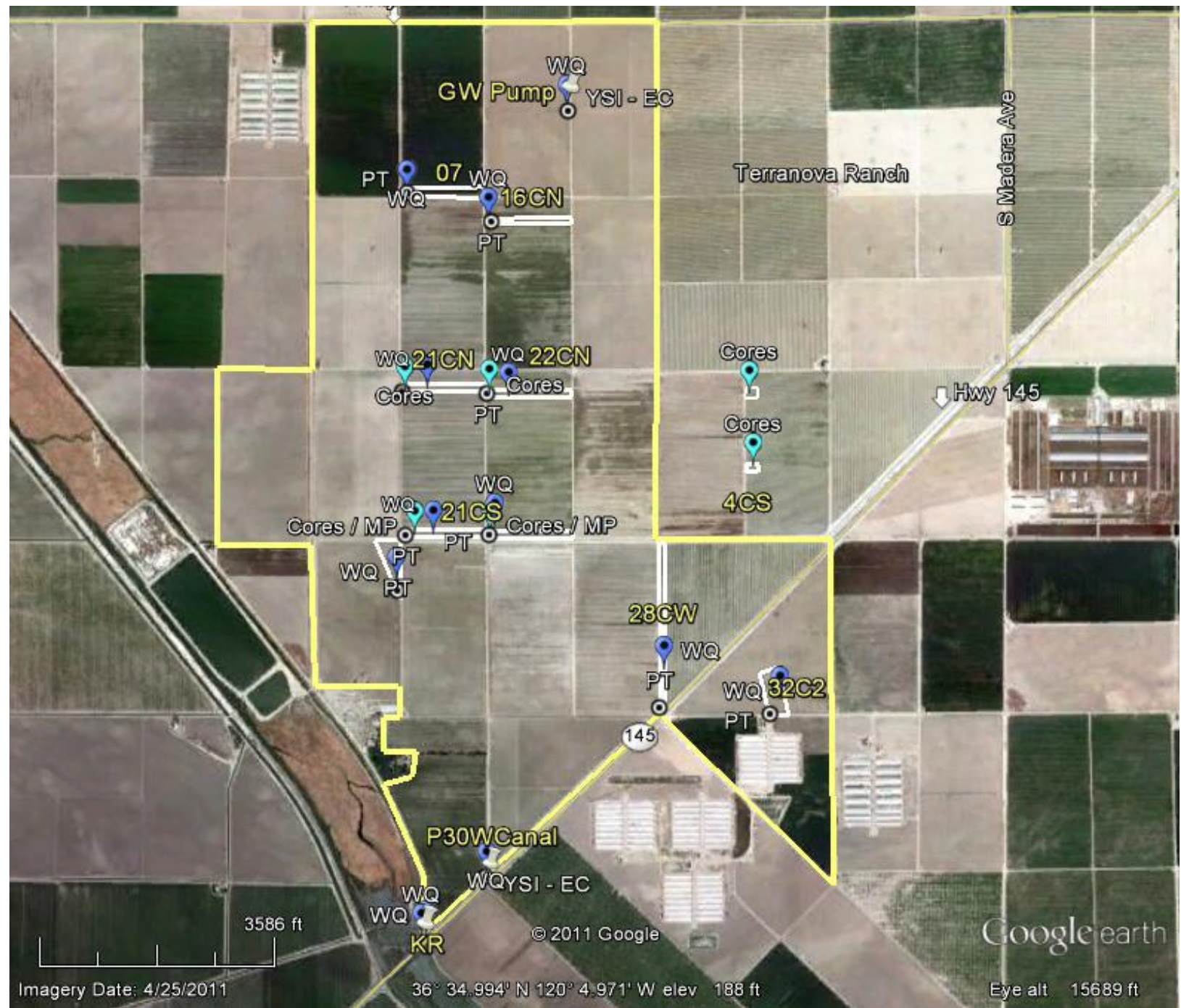

\section{Figure $3 . \quad$ Study site.}

The study site was conducted on an approximate 1000 acres. Intensive hydrologic, soil and water quality monitoring were conducted at check locations as identified in the above map: PT = pressure transducers for water level measurements; YSI = YSI data sondes for EC and temperature; Cores = Soil Cores for lithology and soil moistures; MP = soil moisture probes for EC, volumetric water content and temperature; $W Q=$ discrete water quality sampling. Site names are in green. 


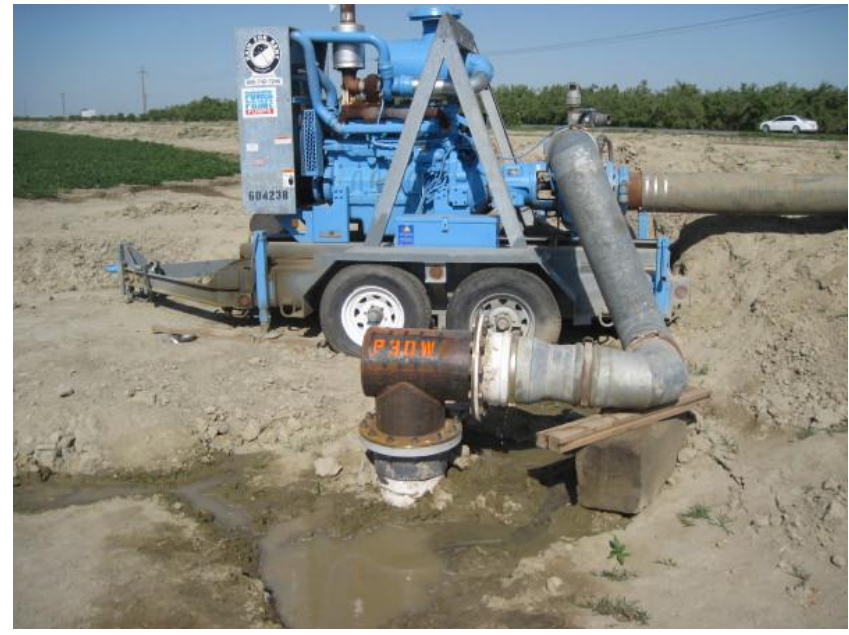

\section{Figure 4. Diversion Pump (30W)}

Pumps and engines were rented and connected to piping to pull water from the diversion canal to capture water from the James Bypass and divert onto agricultural fields.

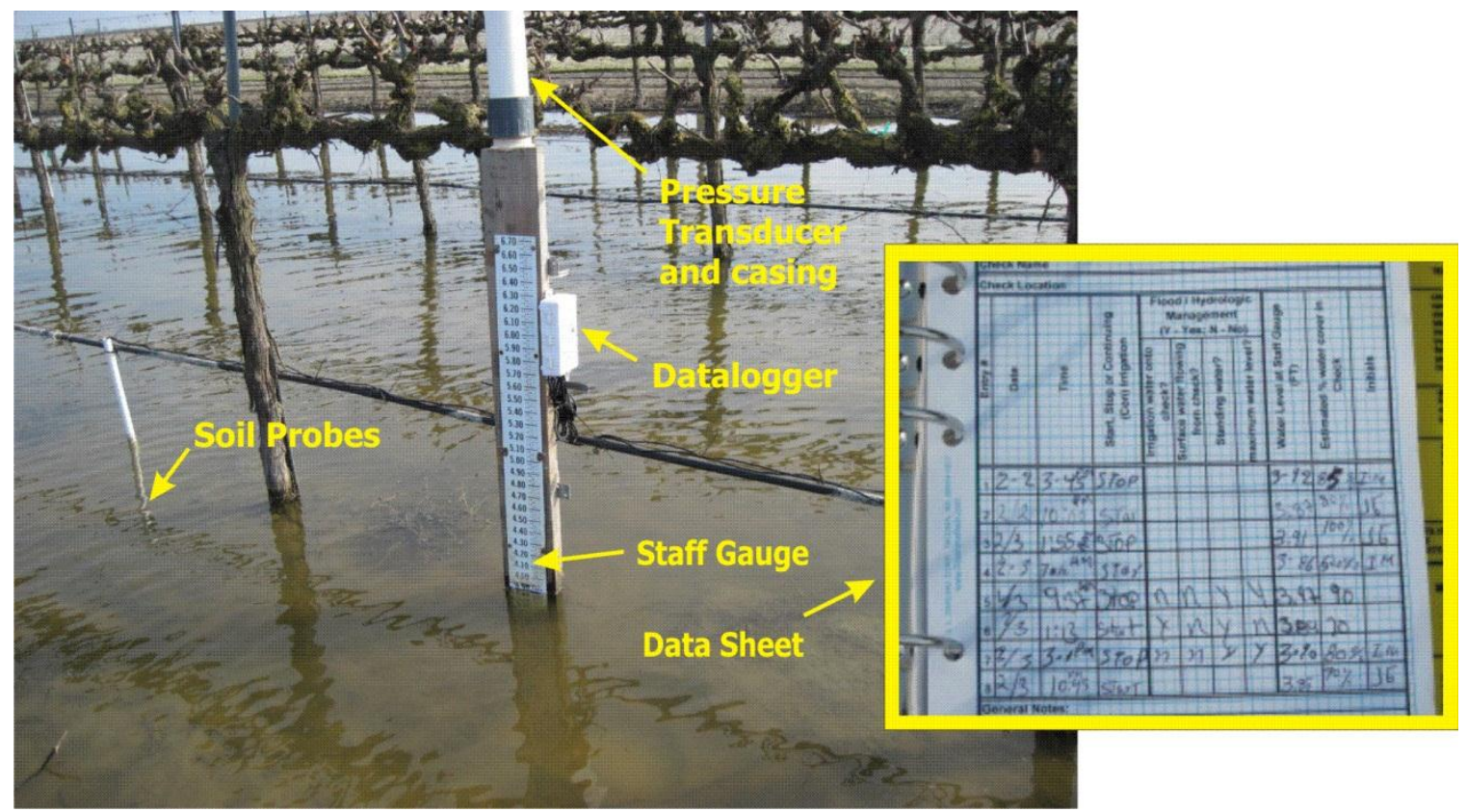

\section{Figure 5. Instrumentation at a Check Location, F22CS.}

Typical monitoring conducted at a check location. Data logger measured soil EC and temperature on 15 minute intervals. Soil probes were installed in replicate at depths of 6 " and 24 " at locations F21CS (Field 21 check at south of field) and F22CS. Soil probes at F21CS were also installed at 48" depth. Pressure transducers measured water level at 15 minute intervals. Irrigators recorded staff gauge values and those values were used to calibrate the pressure transducers. 
Agreement No. 68-9104-128

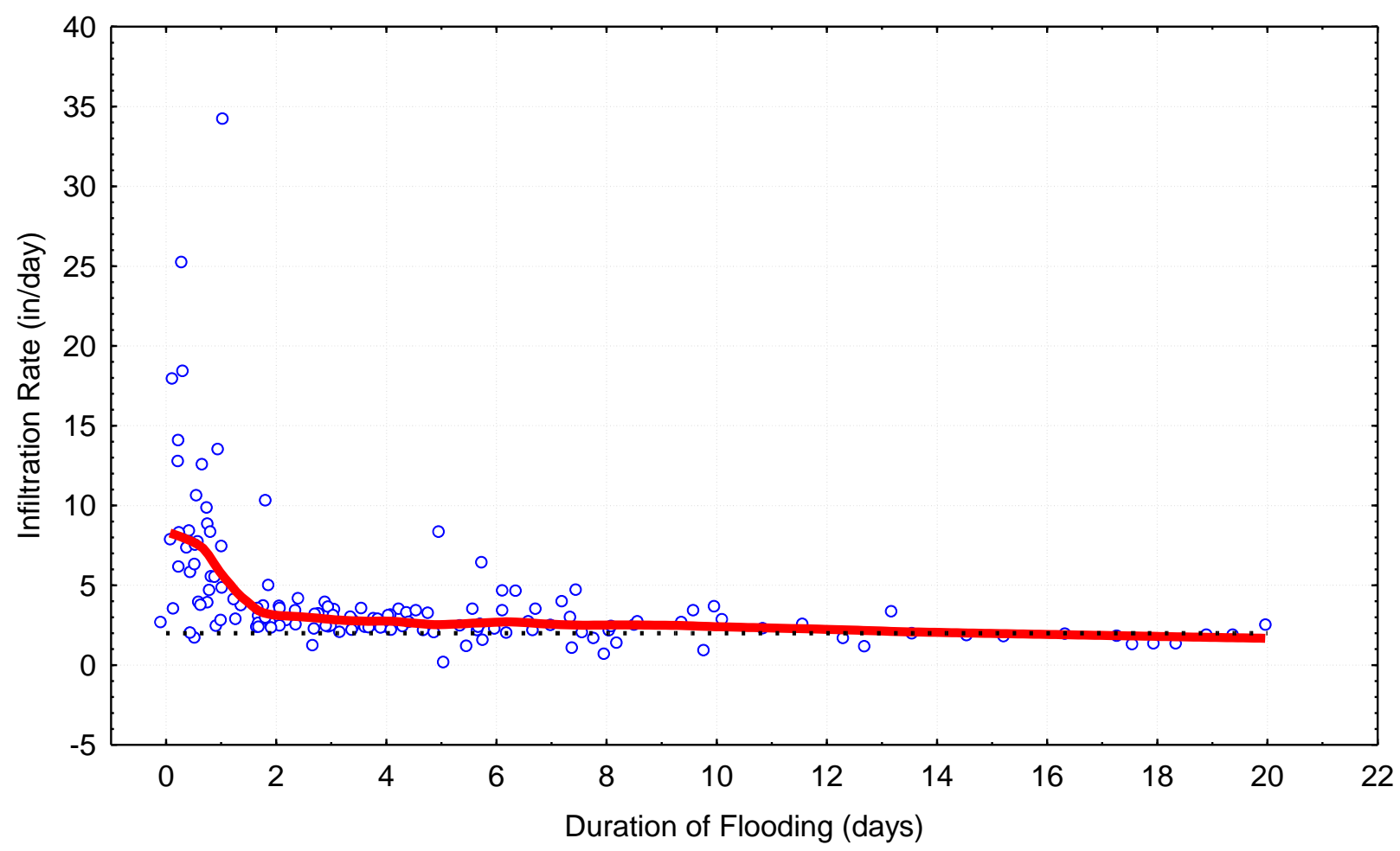

\section{Figure 6. Infiltration Rates}

Infiltration rates were measured at the check locations using pressure transducers. Transducers measured rates water levels dropped after water levels had been raised in the check through diverting flood flows onto the checks. No surface inflows on or outflows off occurred while infiltration rates were being determined through water level changes. 
Agreement No. 68-9104-128
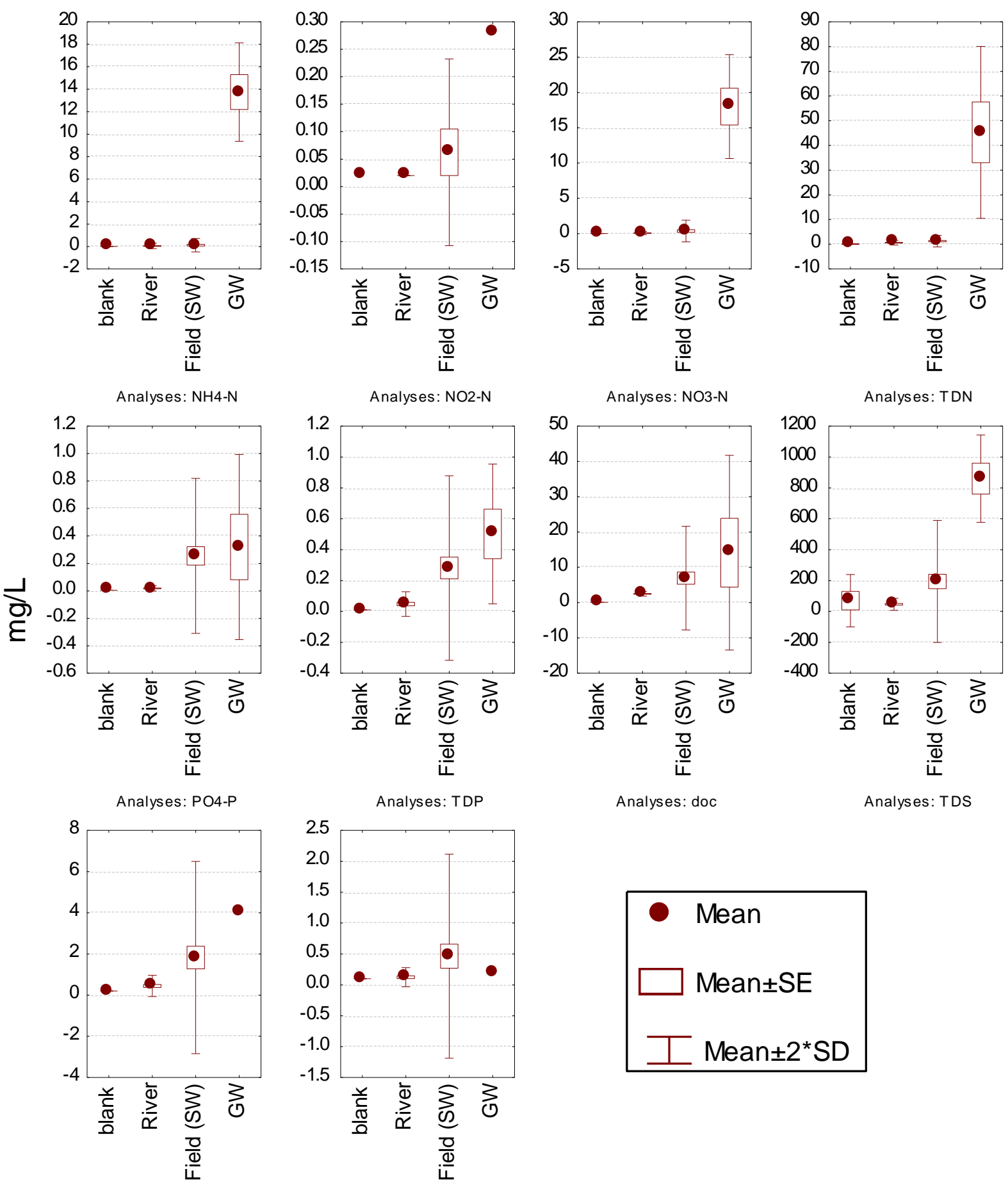

Analyses: doc

Analyses: TDS

Analyses: TSS C

Analyses: TSS N

Sample Location

Figure 7. Water Quality Analyses Results

Samples taken on 5/5, 5/17 and 6/15 2011 at the Kings River. Data analyzed across four locations (from the Kings River, at checks being irrigated with diverted storm flows, from a groundwater pump) plus a blank. 


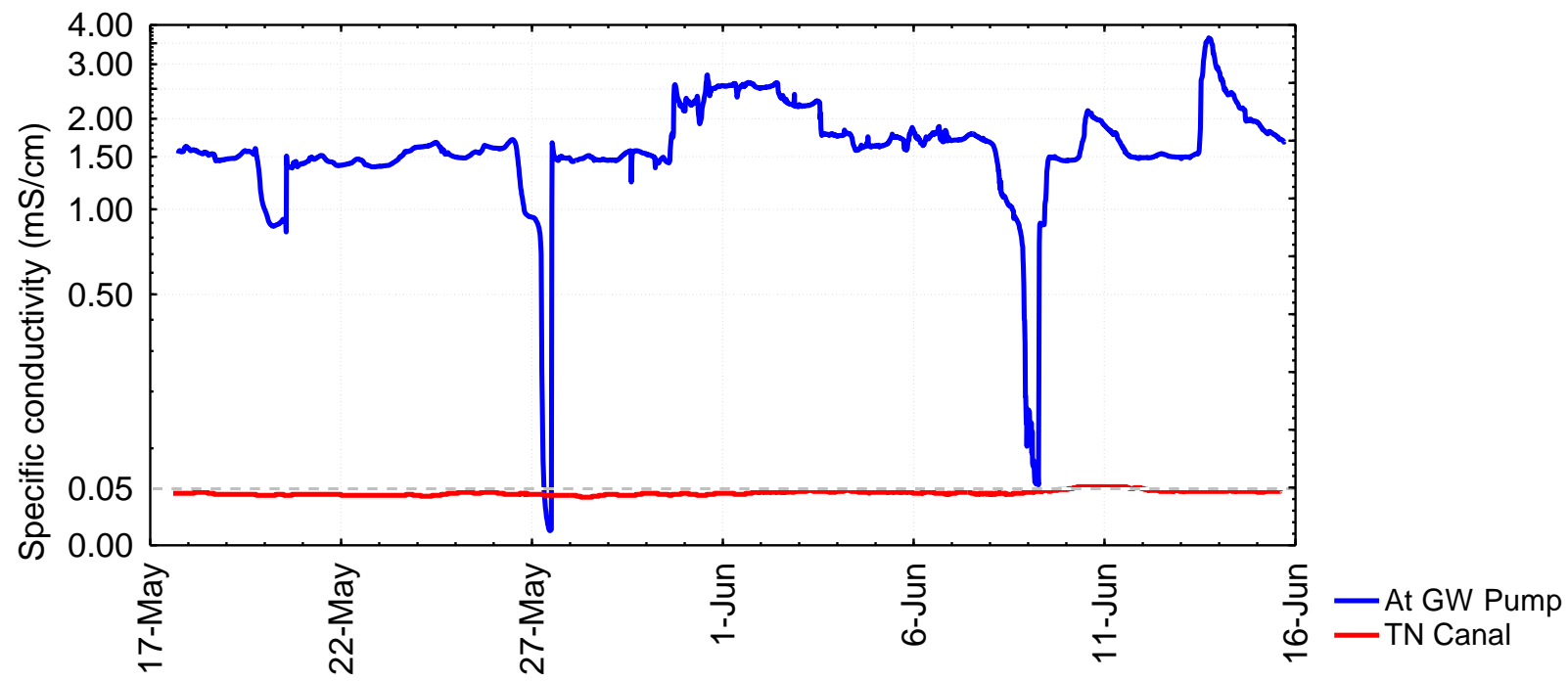

Figure 8. $\quad$ YSI Data comparison

Electrical conductivity (as specific conductivity) was measured at the diversion canal (TN canal) and at a groundwater pump (At GW Pump) used to irrigate fields with groundwater. Electrical conductivity (EC) levels in pumped groundwater were typically 30 to 60 times higher than found in water being diverted from the Kings River at the James Bypass. 


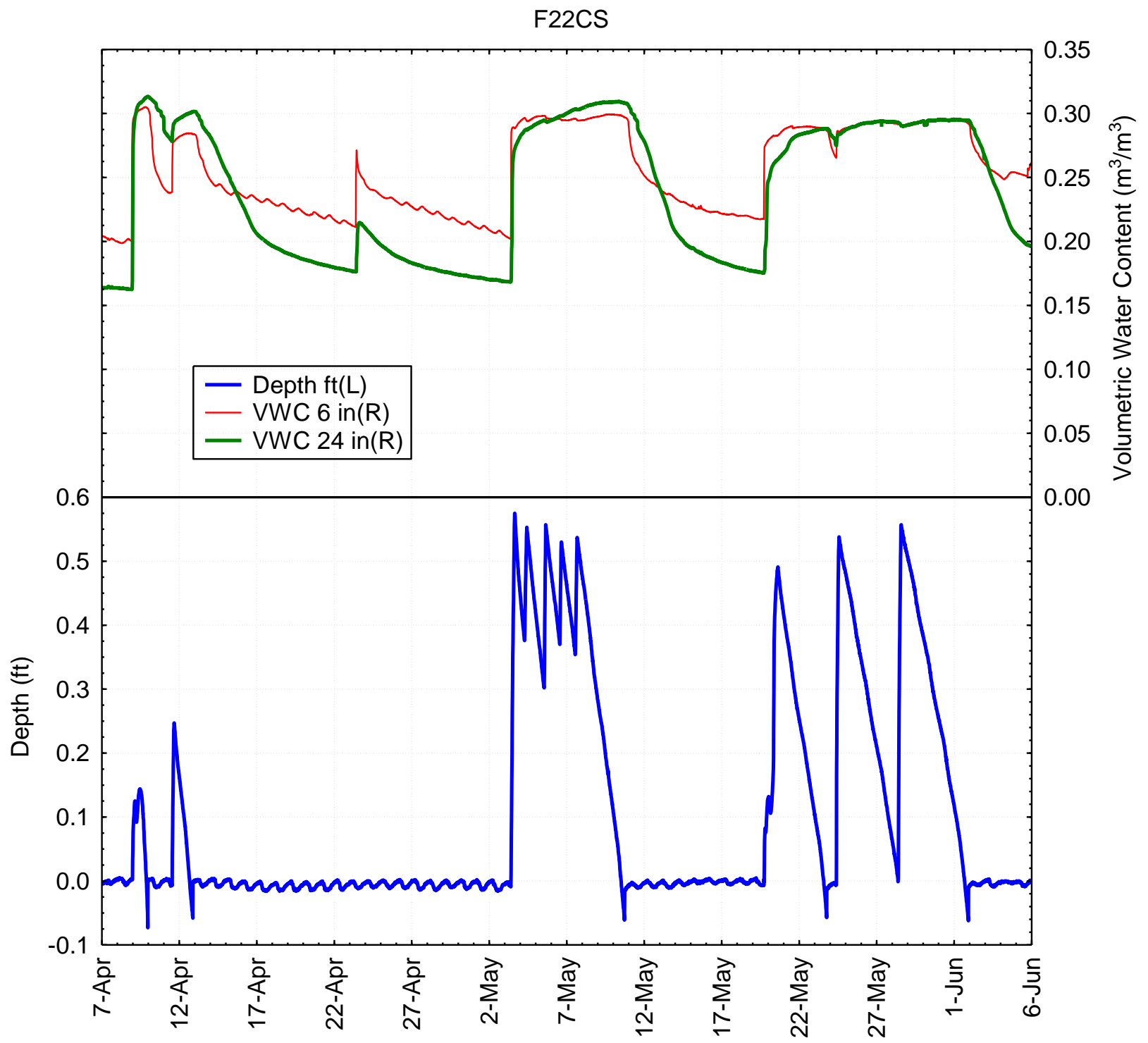

Figure 9. Soil moisture in response to April through June recharge activities at F22CS, 2011.

Data shown response in soil volumetric moisture content (top) at 6 and 24 inch depths in response to surface applied flood flows at check location F22CS. Volumetric moisture content data is an average of three replicate probes at each depth. Standing water on the fields led to soil VWC of about $30 \%$ by volume. Water remained above field capacity while standing water was on the field and for a period after no standing water was measured. During this period water moved downward through the root zone. 


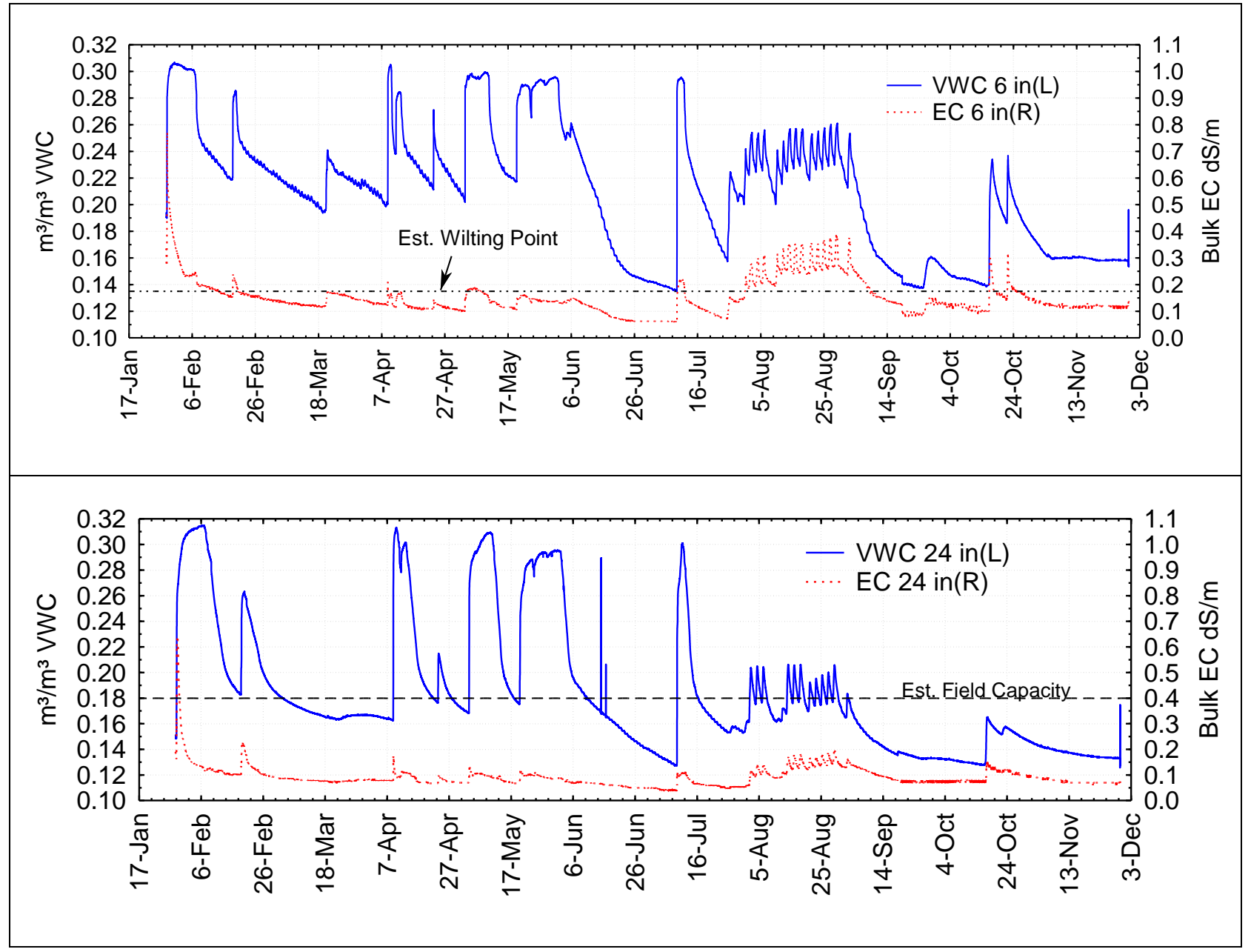

Figure 10. Measured changes in EC (ds/M) at F21CS replicates at depths of 6, 24 and 48 inches, 2011 at F22CS, Recharge Scenario

Salt levels in the root zone, as measured with EC, dropped from initial levels of about $0.8 \mathrm{dS} / \mathrm{m}$ to 0.1 $\mathrm{dS} / \mathrm{m}$ at a soil depth of 6 inches and from 0.65 to $<0.1 \mathrm{dS} / \mathrm{m}$ at a soil depth of 24 inches. With each flood event, EC levels changes in response to changes in VWC, slightly higher with higher VWC values and decreasing with decreasing VWC values. This trend suggested applied surface waters remobilized the movement of salts in the soil column. Summer irrigation with groundwater and late season flushing with groundwater temporarily increased EC levels but those levels decreased with decreasing VWC, suggesting higher salinity water passed through the water column and that pore water tightly associated with soils retained low EC waters. 


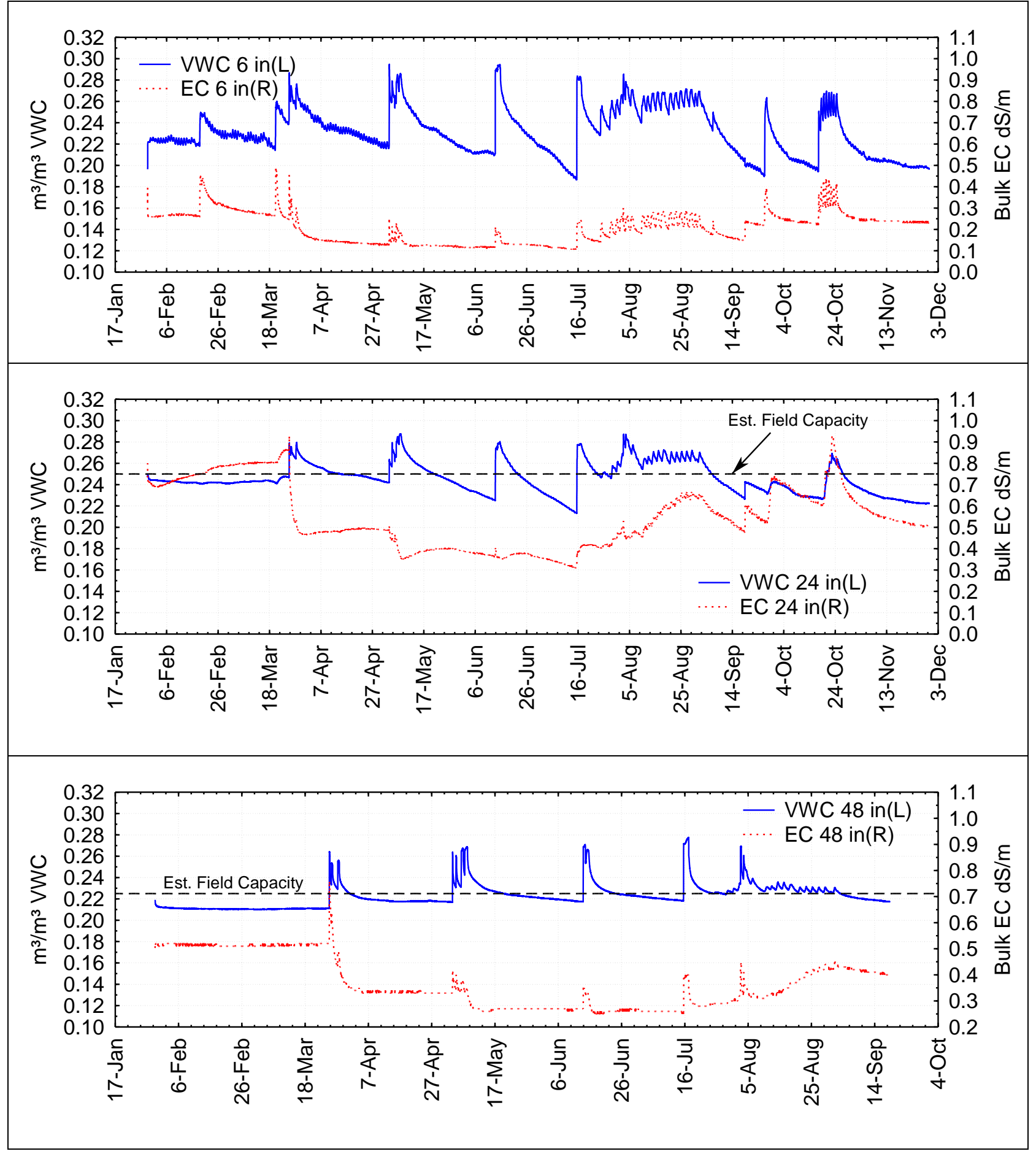

Figure 11. Measured changes in EC (ds/M) at F21CS replicates at depths of 6, 24 and 48 inches, 2011, at F21CS, over-irrigation scenario.

Field 21 received about $40 \%$ of the applied surface flood flow water as Field 22 (Table 5 ) and EC levels in the soils were higher than measured in Field 22. Application of flood flows reduced EC levels to about $0.1 \mathrm{dS} / \mathrm{m}$ at a 6 " depth but were insufficient to presumably displace tightly bound pore waters. After the application of decrease EC levels much below $0.3 \mathrm{dS} / \mathrm{m}$ in deeper soils. With summer irrigation, EC levels increased to about $80 \%$ of initial conditions. 


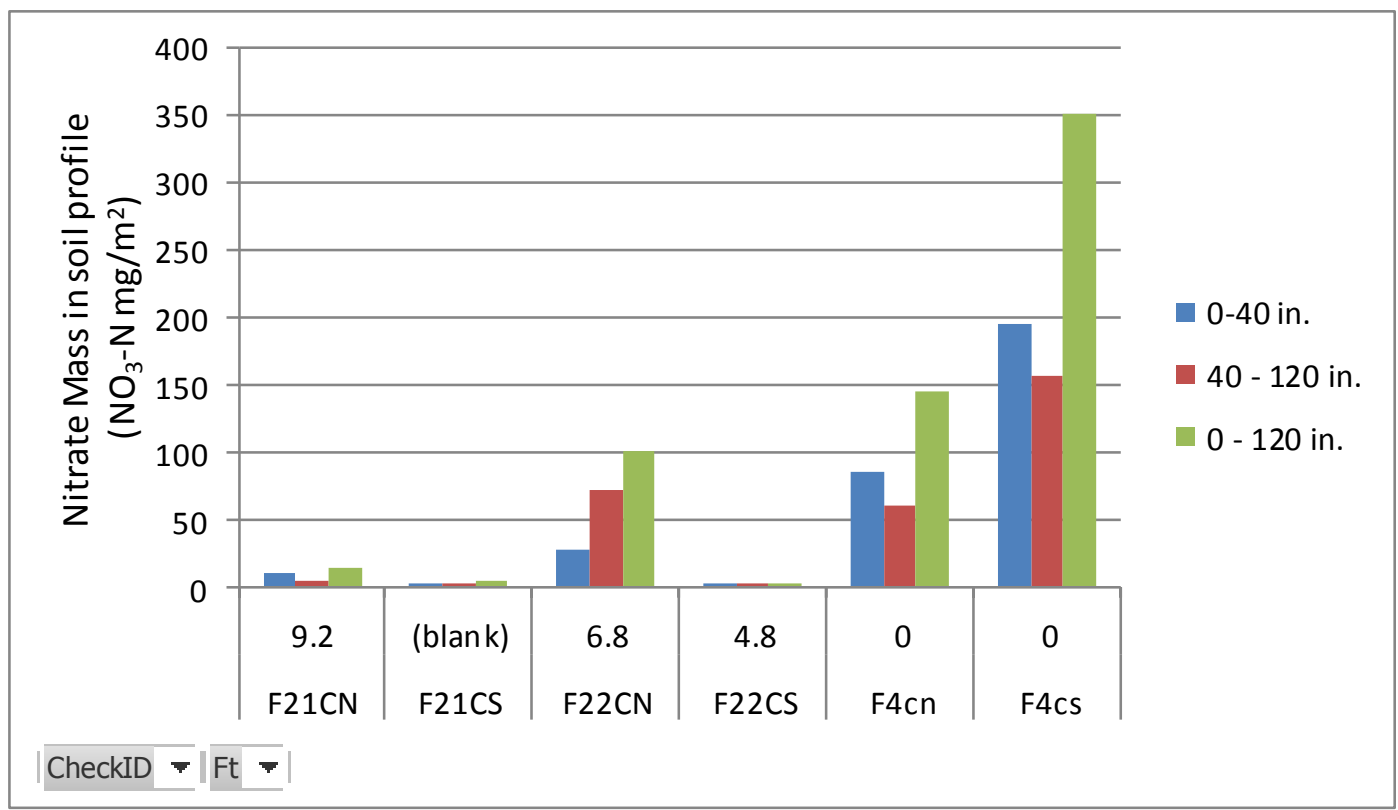

Figure 12. Nitrate in top 120 inches of the soil layer, November 2011 - post irrigation Figure shows nitrate in top 120 inches $(300 \mathrm{~cm})$ of the soil profile $\left(\mathrm{mg}-\mathrm{N} / \mathrm{m}^{2}\right)$ and the amount of water applied at each check (Ft) at replicated checks at Fields 4, 21 and 22. Checks at Fields 21 and 22 received winter and fall flood waters as presented in meters. NO3-N mass found in Field 4 is about an order of magnitude greater than that found in all the other checks except for $\mathrm{F} 22 \mathrm{CN}$. On average, nitrate mass found in the soil cores in Fields 21 and 22 is less than $15 \%$ the mass found in Field 4 soil cores. 


\section{Nitrate}
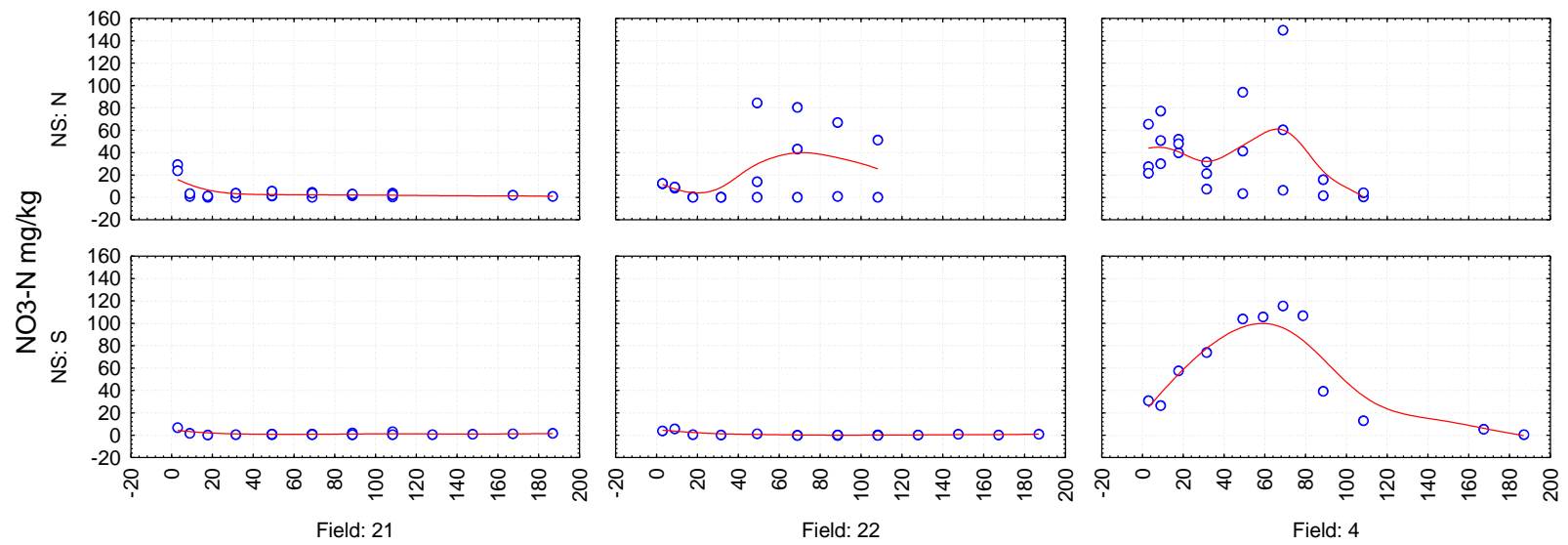

\section{Electro conductivity}
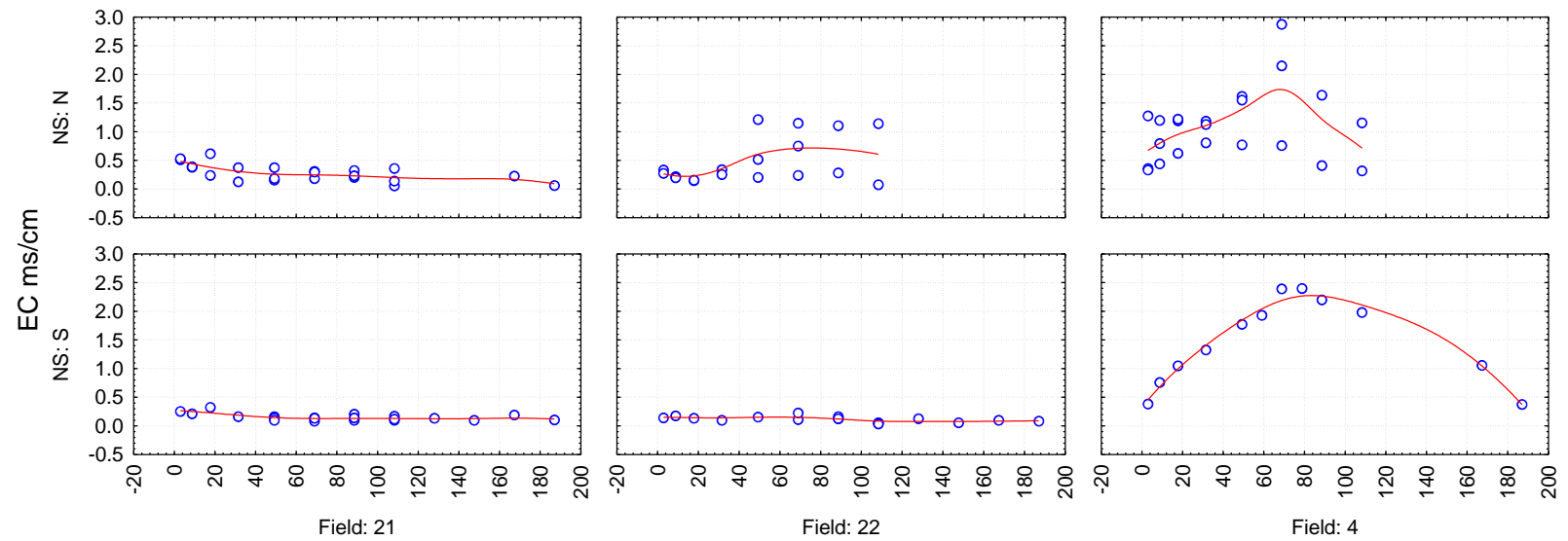

Soil Depth (inches)

\section{Nitrate v EC}

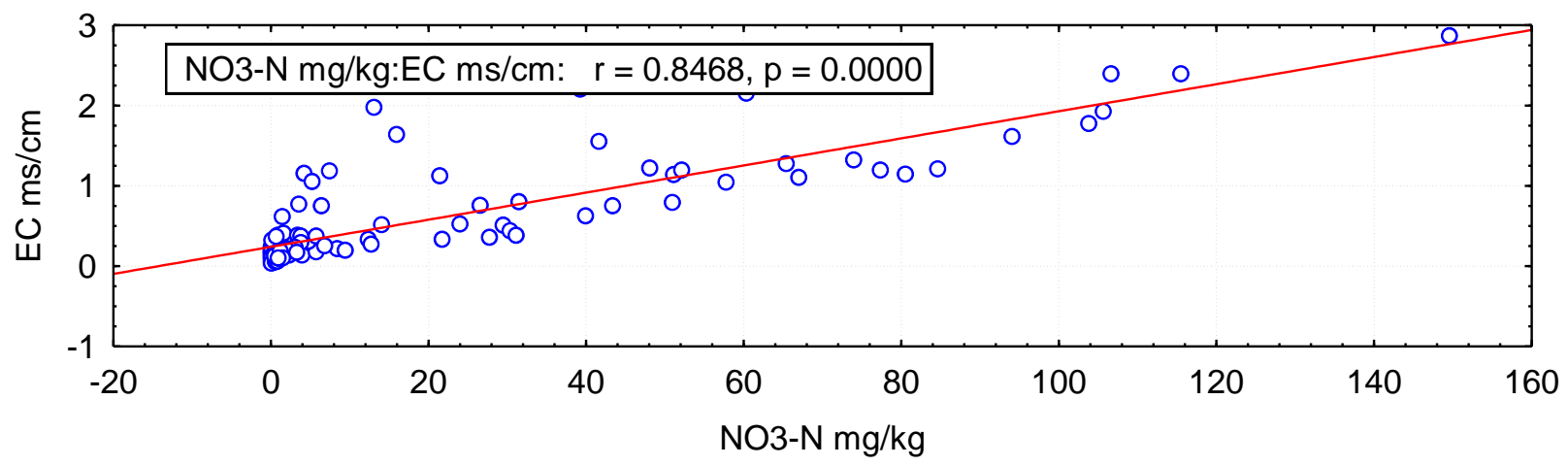

\section{Figure 13. Geoprobe pore water EC and nitrate concentrations with Depth}

Soil cores were taken with the Geoprobe to a depth of 200 inches, using north and south replicate checks (Figure 3) for three checks with different hydrologic regimes are shown: normal drip using GW - Field 4; over-irrigation during the winter with flood flows - Field 21; and direct recharge in the winter with over irrigation into the summer - Field 22. Nitrate and EC levels for Field 4 were elevated throughout the profile for the soil cores and significantly different than values measured in check locations within Fields 21 and $22(p<0.05)$. EC and nitrate values in Fields 21 and 22 were generally low. The relationship 
On-Farm Flood Flow Capture As a Cost Effective Method to Recharge Groundwater and Reduce Downstream Flood Risks

Agreement No. 68-9104-128

between EC and nitrate concentrations was significant and well correlated $(r=0.85, p<<0.01)$. Depth is average depth of soil core collected.

A. Flow Past Turnout

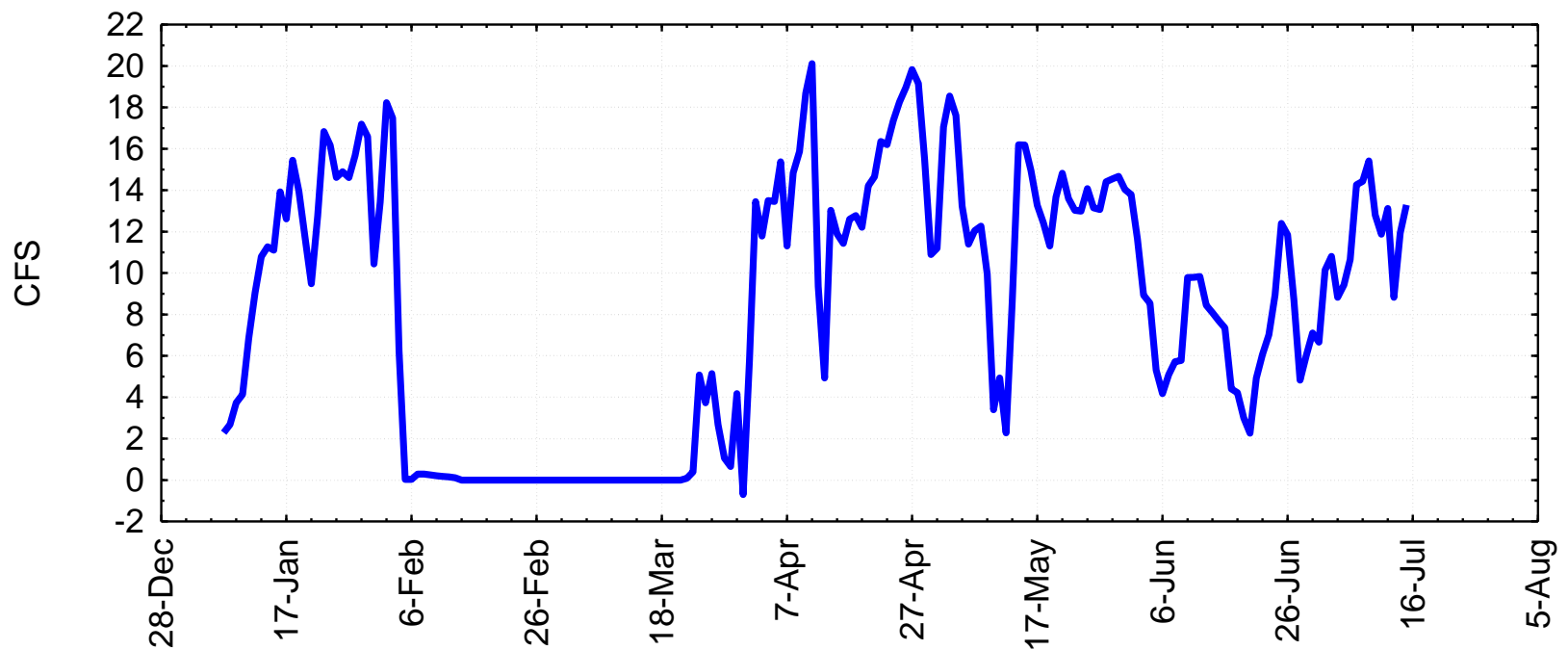

B. Flow Past James Weir

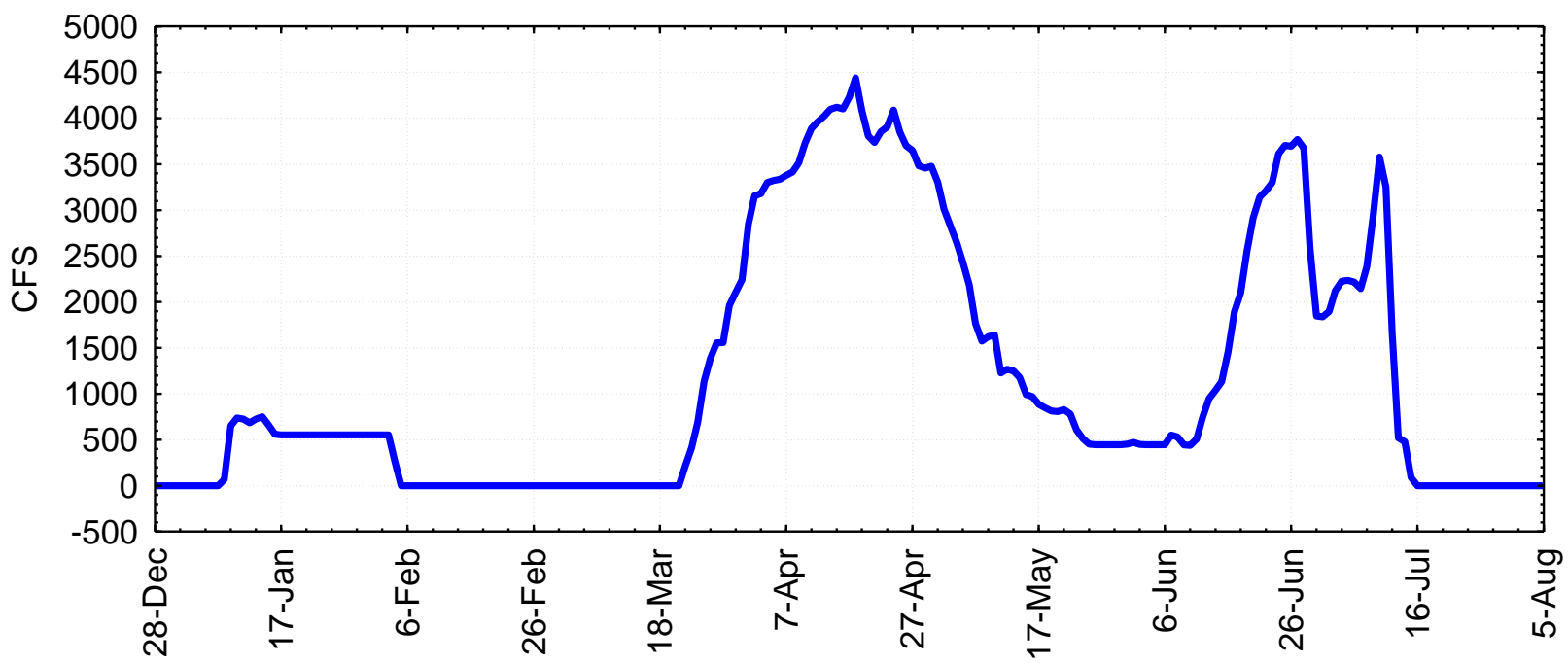

Figure 14. Kings River flows diverted into Terranova through the turnout and past the James Weir into the James Bypass, 2011/12.

Captured flood flows were diverted from the James Bypass onto Terranova Ranch through a turnout. Diverted flows ranged from $2-22 \mathrm{cfs}$. The total volume diverted to the ranch was calculated at 3,116 ac$\mathrm{ft}$. Diverted flows were two orders of magnitude below flows past the James Weir which ranged from 500 to nearly 4500 CFS 


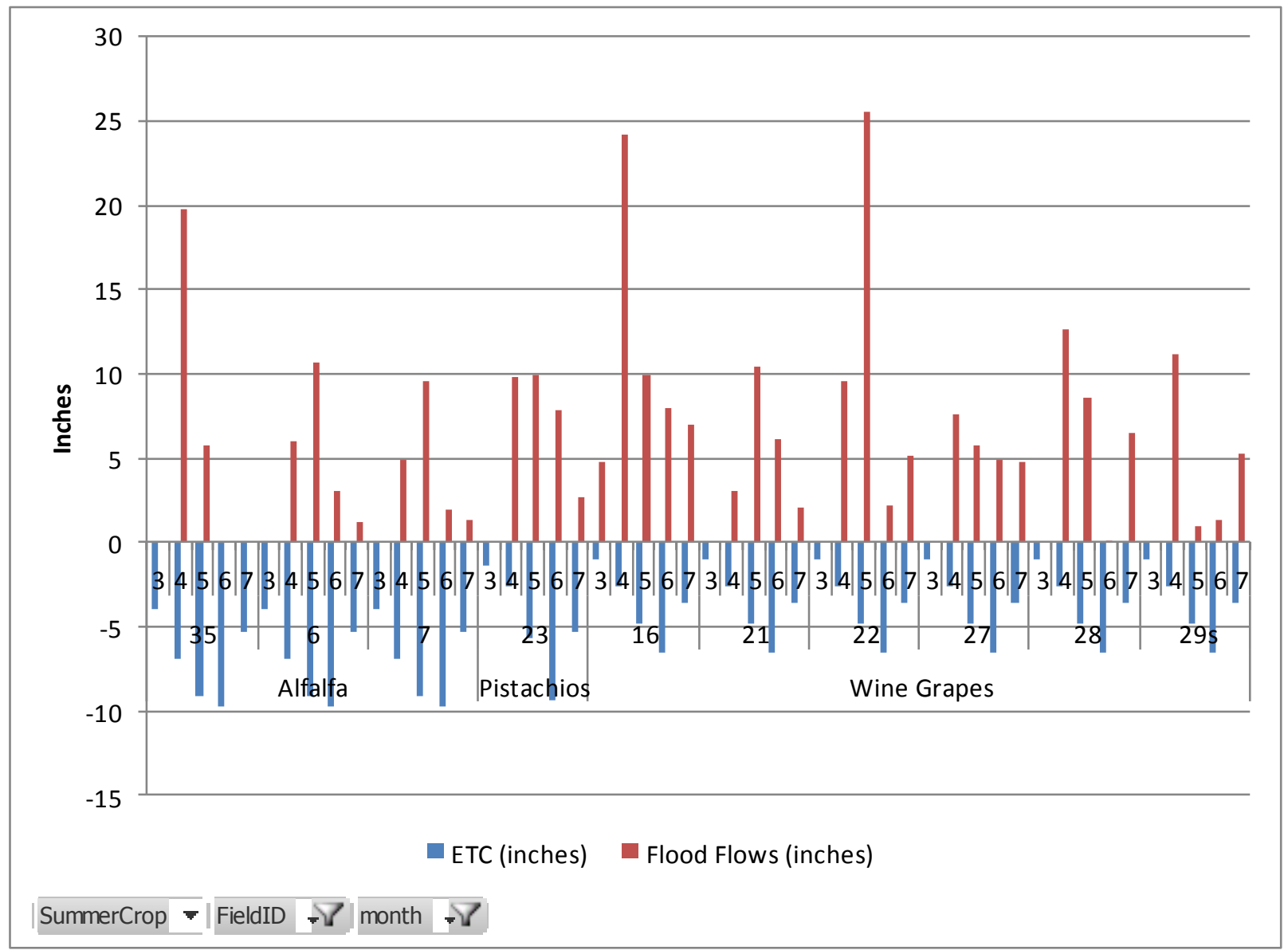

Figure 15. Monthly water applied and ETc losses for Key Fields, January - July 2011

Data shows total flood flows applied for different fields which received more than 16 inches of applied flood flows water from January through July, 2011. Most water was applied from March through midJuly. 
On-Farm Flood Flow Capture As a Cost Effective Method to Recharge Groundwater and Reduce Downstream Flood Risks Agreement No. 68-9104-128

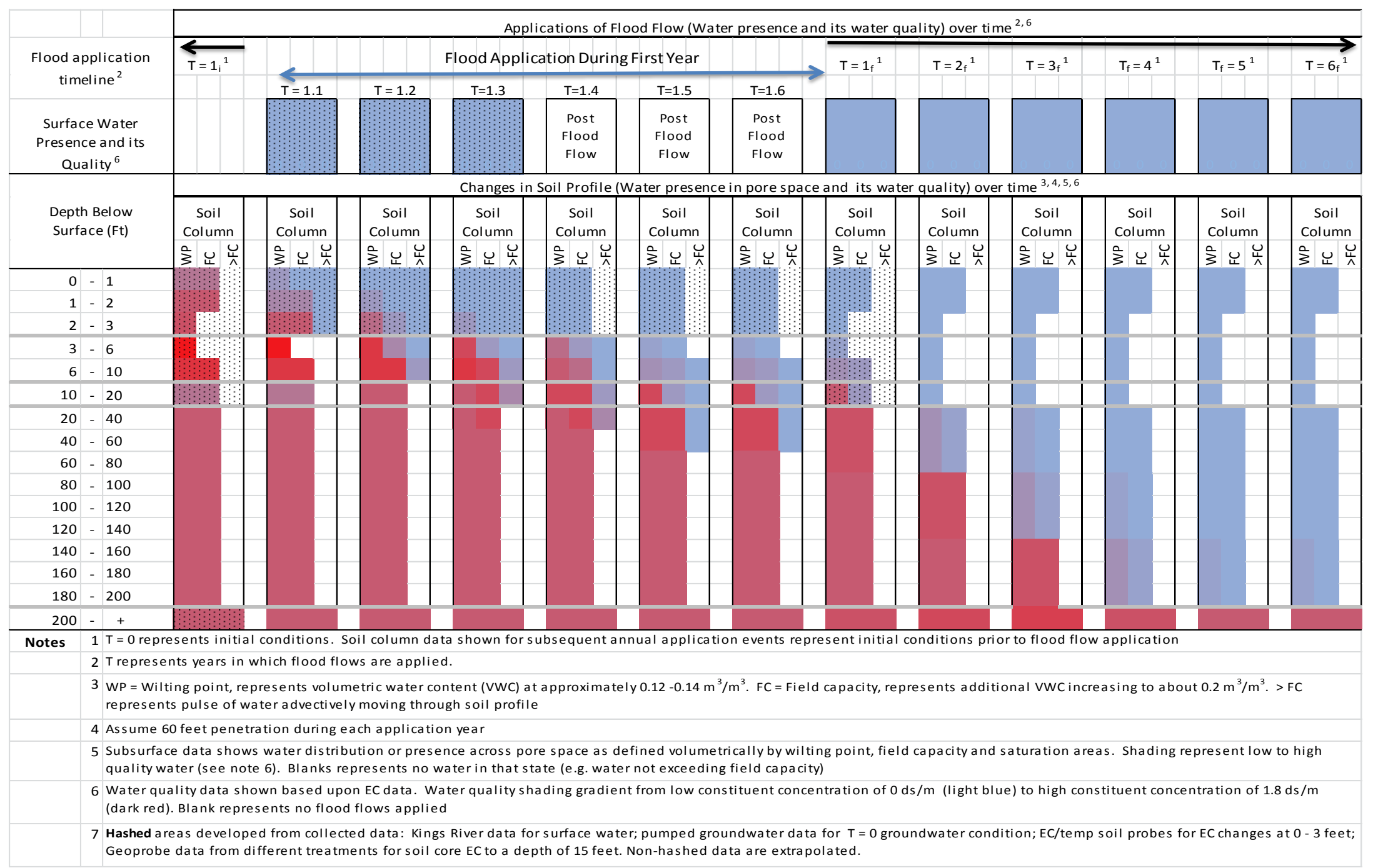

Figure 16. Conceptual Model of Nitrate and Salt movement during annual periods of flood flow capture and recharge

Model represents movement of nitrate and salts down the soil column through changes in the concentrations for tightly bound water in micro pores (wilting point), less tightly bound water (between the wilting point and field capacity) and mobile water (water associated with field capacity). Changes occurring over the first year and then by the end of subsequent years are presented. 
Agreement No. 68-9104-128

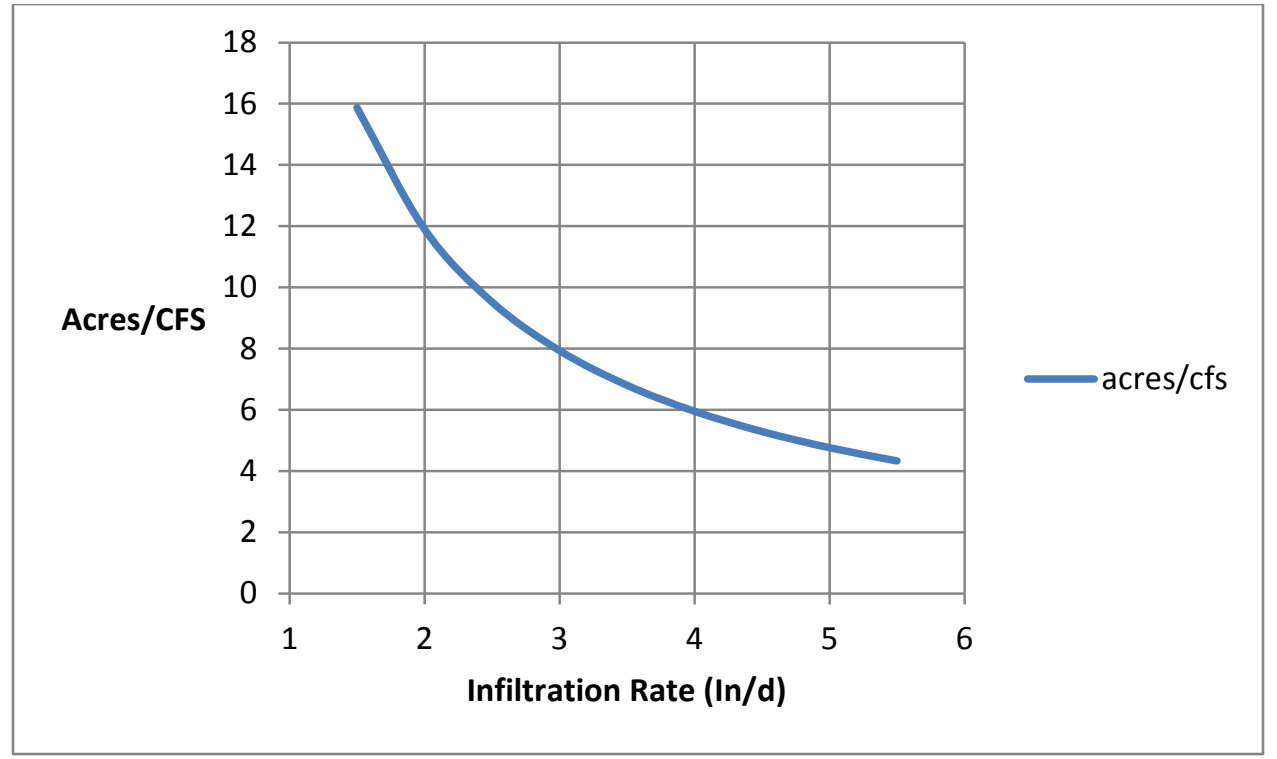

Figure 17. Predicting Acres/CFS ratio

Figure shows the ratio of acres needed for direct recharge to flow past the James Weir as a function of infiltration rate.

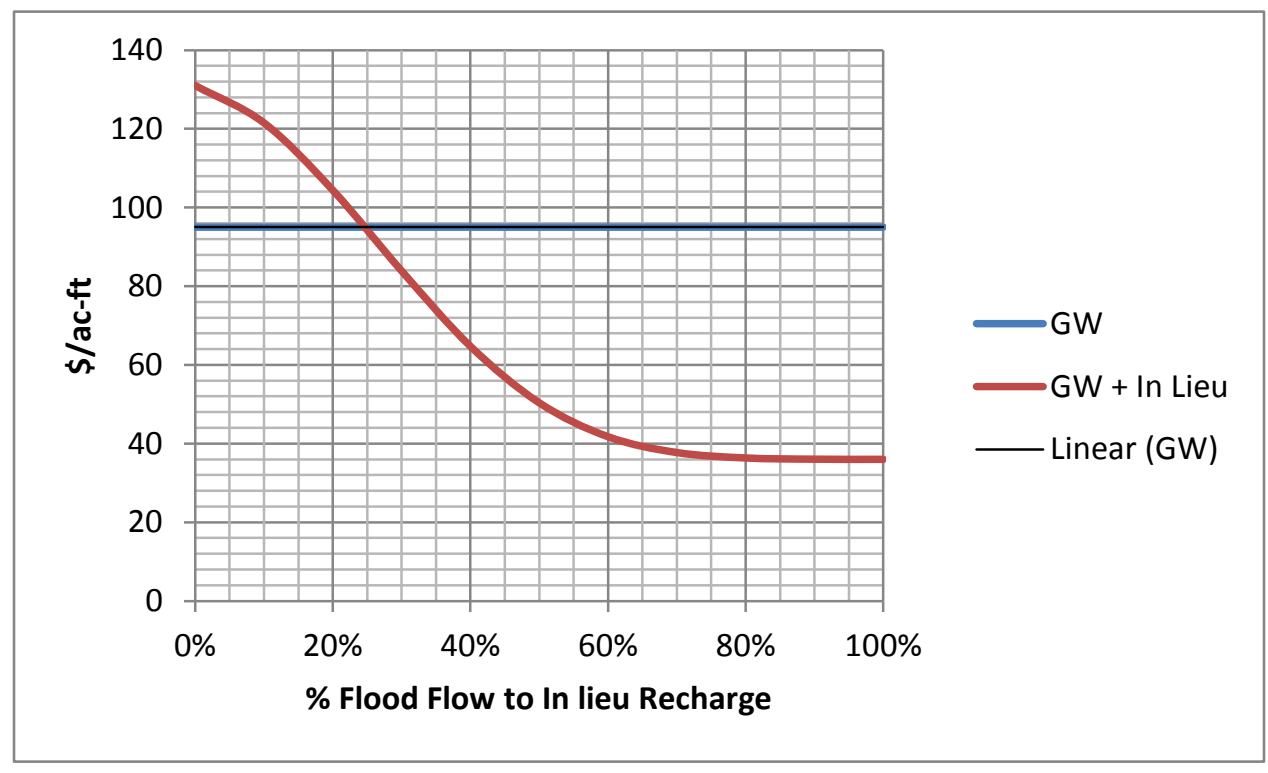

Figure 18. Costs of Combined Irrigation and Direct Recharge

The above graph shows the combined cost to irrigate and capture flood flow for recharge on an ac-foot basis. When flood flows are captured but not utilized for in lieu recharge purposes, the cost to capture 1 ac- $\mathrm{ft}$ and to irrigate with 1 ac- $\mathrm{ft}$ are $\$ 131 / \mathrm{ac}-\mathrm{ft}$; the cost of flood flow capture ( $\$ 36 / \mathrm{ac}-\mathrm{ft}$ ) plus the cost of groundwater pumping (\$95/ac-ft). When $100 \%$ flood flows are used for in lieu recharge, total cost drop to the cost of flood flow capture as no groundwater is pumped. At about $25 \%$ of captured flood flows being utilized for in lieu recharge, the costs to capture flood flows and to irrigate dropped below the cost of irrigation alone. 


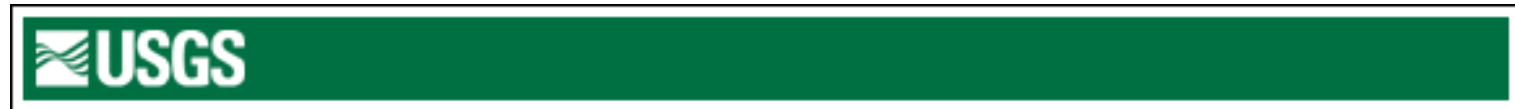

USGS 11253500 JAMES BYPASS (FRESNO SLOUGH) NR SAN JOAQUIN CA

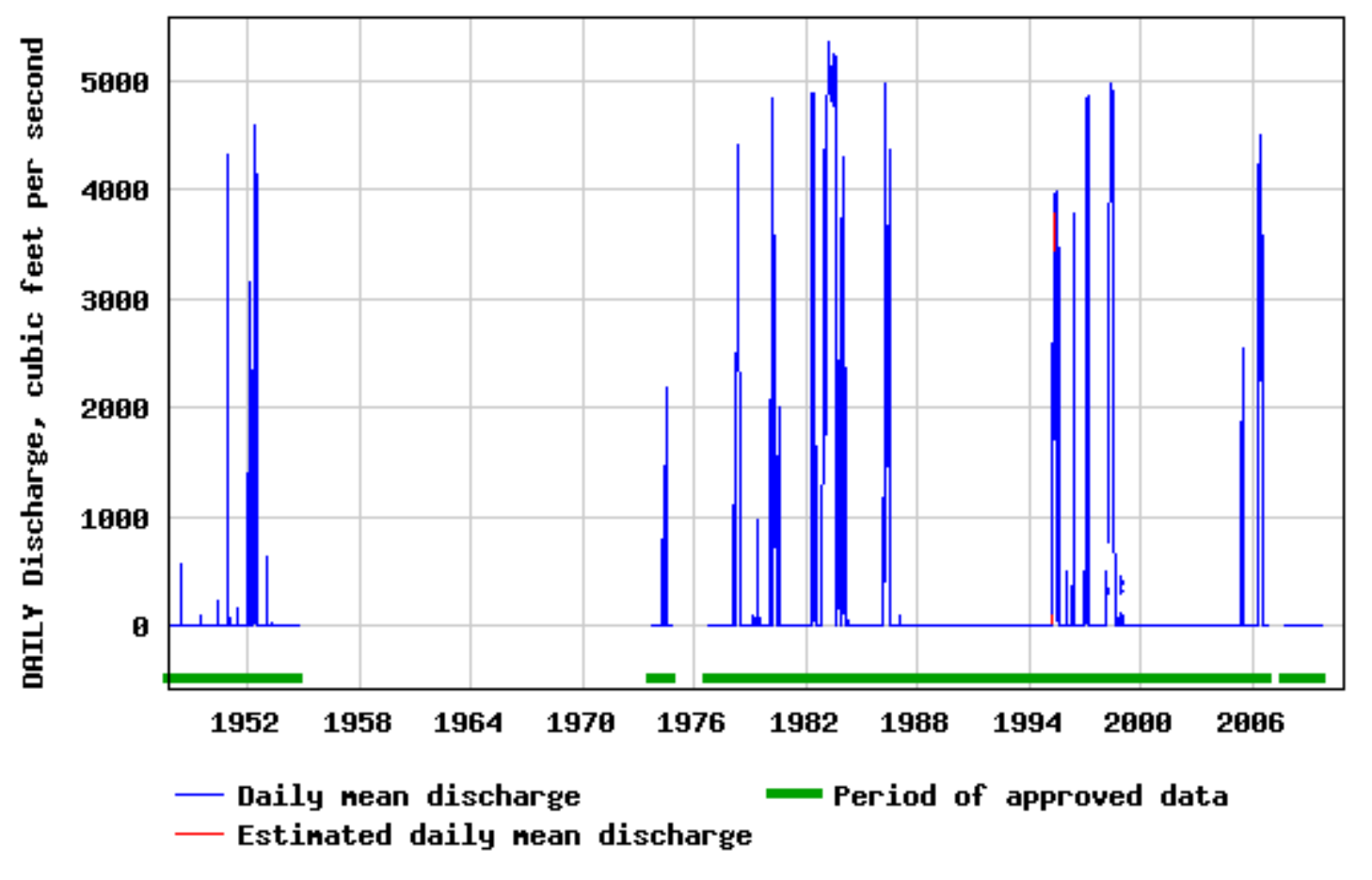

Figure 19. Flows past the James Bypass represent excess flood flows from the Kings River Basin

USGS data from 10/1/1947 - 9/30/54, 10/1/1973 - 9/30/1974, and 10/1/1976 - 9/30/2009. 
On-Farm Flood Flow Capture As a Cost Effective Method to Recharge Groundwater and Reduce Downstream Flood Risks

Agreement No. 68-9104-128

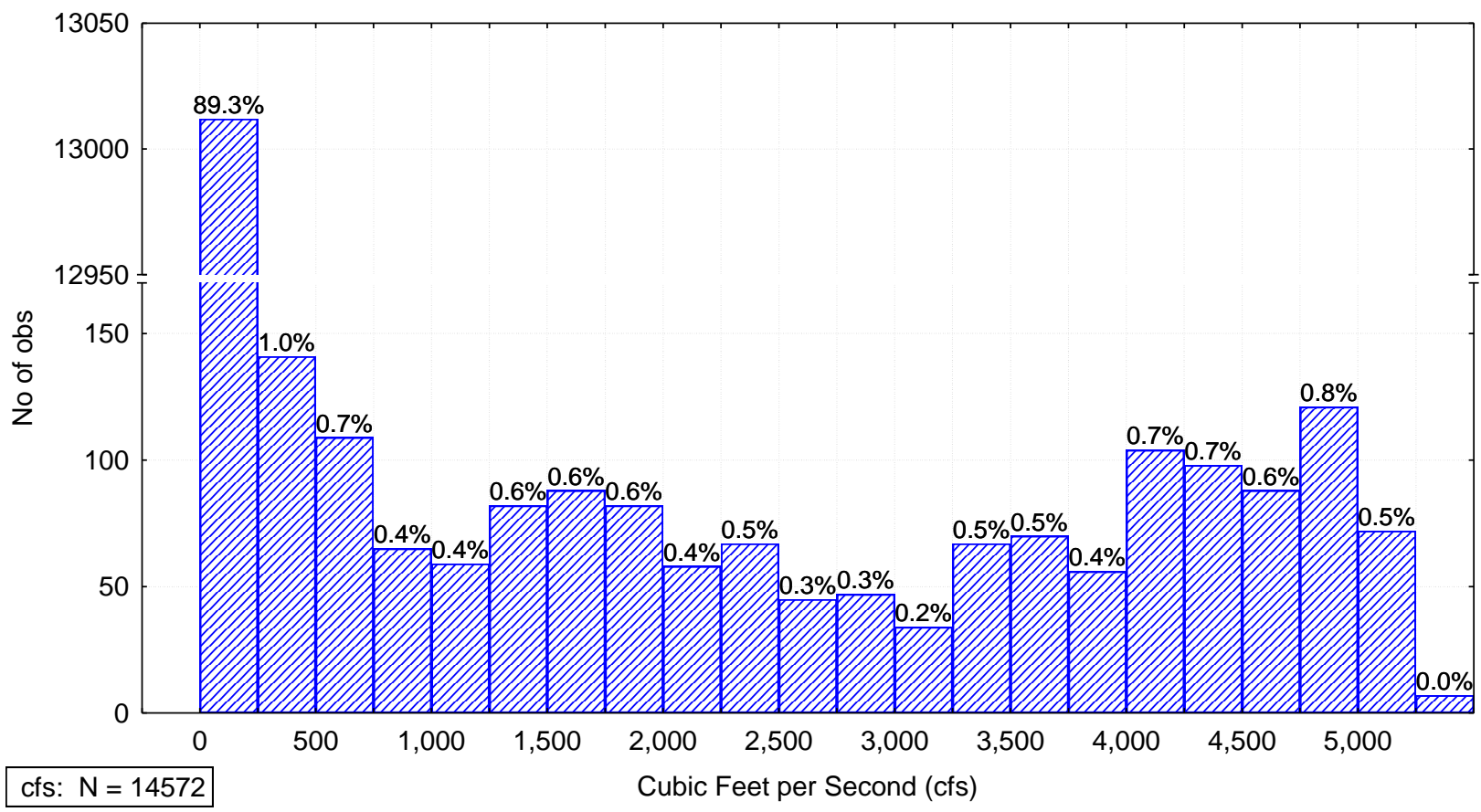

Figure 20. Histogram of Flow at the James Weir with focus on flows $>\mathbf{2 0}$ cfs.

Approximately $90 \%$ of flows at the James weir are measured to be $<250 \mathrm{cfs}$. The remaining flow rates are relatively evenly distributed from 500 to 5500 cfs. An exponential distribution generally describes the distribution. 
On-Farm Flood Flow Capture As a Cost Effective Method to Recharge Groundwater and Reduce Downstream Flood Risks

Agreement No. 68-9104-128

\section{Tables}


On-Farm Flood Flow Capture As a Cost Effective Method to Recharge Groundwater and Reduce Downstream Flood Risks Agreement No. 68-9104-128

\section{Table 1. Experimental Design}

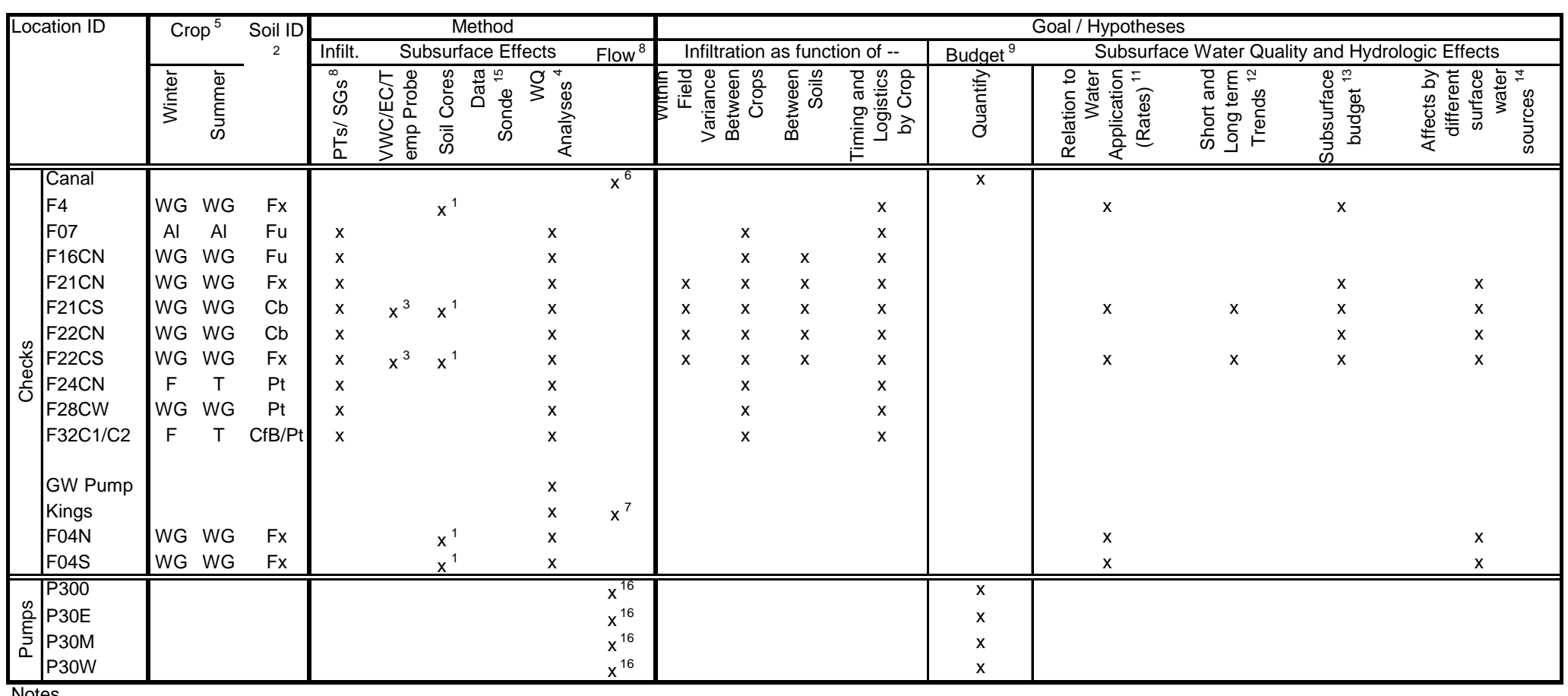

1 Soil cores subdivided by following depths (cm): 0-15,15-30, 30 - 60, 60 - 100, 100 - 150, 150 - 200, 200 - 250, 250 - 300, 300 - 350, 350 - 400, 400 - 450, 450 - 500)

$2 \mathrm{Fu}=$ Fresno fine sandy loam; $\mathrm{Fx}=$ Fresno-Traver complex; $\mathrm{Cb}=$ Cajon loamy coarse sand, saline alkali; $\mathrm{CfB}=$ Calhi loamy sand, 3 to 9 percent slopes; $\mathrm{Pt}=\mathrm{Pond}$ fine sandy loam

3 At each location 3 replicated probes at 6 and 24 inch depths. At F21CS an additional probe placed at 48 inches

4 Water analyzed for phosphorus and nitrogen species, EC, $\mathrm{pH}$, TDS, TSS

$5 \mathrm{WG}=$ Wine grapes; $\mathrm{Al}=$ Alfalfa; $\mathrm{F}=$ Fallow; $\mathrm{T}=$ Tomatos

6 Flow determined with AVM

7 Flow provided through USGS monitoring station

8 Collected data includes field notes from irrigation staff regarding timing and management

9 Pump data identified distribution of flows to fields on a daily basis

$10 \mathrm{WG}=$ Wine grapes; $\mathrm{Al}=$ Alfalfa; $\mathrm{F}=$ Fallow; $\mathrm{T}=$ Tomatos

11 Recharging with Flood Flows vs. over-irrigating with flood flows vs. drip irrigation and no flood flow application

$12 \mathrm{EC}$ and Moisture content short- and long-term trends to application of captured flood flows and potential impact on groundwater quality

13 Depth to which applied water would be expected to move and expected transport of constituents

14 Comparing water quality from flood flows and from groundwater source and assessment of potential impacts to groundwater quality

15 Datasonde collected data on 15 minute intervals for 2 week deplyment in June and collected EC, temperature, $\mathrm{pH}$, turbidity and DO.

16 Flow data collected manually from meters and pump curve information. Daily record. 
On-Farm Flood Flow Capture As a Cost Effective Method to Recharge Groundwater and Reduce Downstream Flood Risks

Agreement No. 68-9104-128

Table 2. Turnout Monthly Volumes

\begin{tabular}{|ccc|}
\hline Month & Cubic Feet & Ac-Ft \\
\hline \hline 1 & $24,933,191$ & 572 \\
2 & $4,918,676$ & 113 \\
3 & $1,928,207$ & 44 \\
4 & $36,617,924$ & 841 \\
5 & $33,953,689$ & 779 \\
6 & $19,162,238$ & 440 \\
7 & $14,233,748$ & 327 \\
\hline \hline Total & $135,747,671$ & 3,116 \\
\hline
\end{tabular}

Table 3. Laboratory Method Summary

\begin{tabular}{|c|c|c|c|}
\hline & Analyte & Description & Method or Equipment \\
\hline \multicolumn{4}{|c|}{ WATER QUALITY ${ }^{1}$} \\
\hline & TDS & $\begin{array}{l}\text { Gravimetric, drying at } 105 \\
\text { deg C }\end{array}$ & $\begin{array}{l}\text { Method } 2540 \text { B. Standard Methods for the } \\
\text { Examination of Water and Wastewater. 20th ed }\end{array}$ \\
\hline & DOC & UV-persulfate digestion. & Teledyne-Tekmar Phoenix 8000 \\
\hline & $\mathrm{NH} 4$ & Colorimetry & Murphy and Riley, Analytical Chimica Acta 27:31 \\
\hline & PO4 & Colorimetry & Murphy and Riley, Analytical Chimica Acta 27:31 \\
\hline & TDP/TDN & Persulfate digestion & Valderrama, Marine Chemistry 10:109 \\
\hline & NO3/NO4 & Colorimetry & Doane and Horwath, Analytical Letters \\
\hline & TSS $\mathrm{C}$ and $\mathrm{N}$ & $\begin{array}{l}\text { Filtration, elemental } \\
\text { analysis }\end{array}$ & Costech ECS 4010 \\
\hline \multicolumn{4}{|c|}{ Soil Analysis ${ }^{2}$} \\
\hline & Percent moisture & $\begin{array}{l}\text { Gravimetric, drying at } 105 \\
\text { deg } C\end{array}$ & \\
\hline & EC method & Soil:water ratio $=1$ & $\begin{array}{l}\text { A Denver Instruments model } 220 \text { conductivity } \\
\text { meter }\end{array}$ \\
\hline & NO3-N & $\begin{array}{l}\text { Extraction with } 1 \mathrm{M} \mathrm{KCL} \text { by } \\
\text { centrifuge, colormetry }\end{array}$ & Murphy and Riley, Analytical Chimica Acta 27:31 \\
\hline \multicolumn{4}{|c|}{ Notes } \\
\hline 1 & \multicolumn{2}{|c|}{ One day holding time for all water samples } & \\
\hline 2 & Refrigerated & & \\
\hline
\end{tabular}


On-Farm Flood Flow Capture As a Cost Effective Method to Recharge Groundwater and Reduce Downstream Flood Risks

Agreement No. 68-9104-128

Table 4. Statistical Differences between treatments for infiltration rates (in/d).

\begin{tabular}{|c|c|c|c|c|c|c|c|c|c|c|}
\hline & \multirow[t]{2}{*}{ Variable } & \multirow[t]{2}{*}{ crop } & \multirow[t]{2}{*}{ Soil Series } & \multicolumn{6}{|c|}{ Infiltration } & \multirow[b]{2}{*}{$p<0.05$} \\
\hline & & & & $\mathrm{N}$ & mean & $\mathrm{sd}$ & $\mathrm{se}$ & $\min$ & $\max$ & \\
\hline \multirow{9}{*}{ 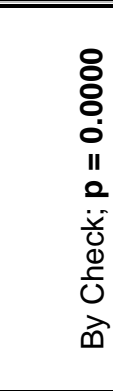 } & $\overline{F 07}$ & alfalfa & $\overline{\overline{F u}}$ & $\overline{\overline{6}}$ & 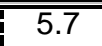 & $1 . \overline{1.3}$ & 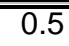 & 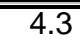 & $\overline{77.1}$ & $\bar{a}$ \\
\hline & F24CN & fallow & $\mathrm{Pt}$ & 23 & 2.7 & 1.6 & 0.3 & 2.0 & 3.4 & a \\
\hline & F32C2 & fallow & $\mathrm{Pt}$ & 10 & 3.5 & 1.5 & 0.5 & 2.4 & 4.6 & a \\
\hline & F16CN & grape & $\mathrm{Fu}$ & 30 & 3.8 & 3.0 & 0.5 & 2.6 & 4.9 & $a$ \\
\hline & F22CN & grape & $F x$ & 34 & 3.2 & 1.3 & 0.2 & 2.7 & 3.7 & a \\
\hline & F22CS & grape & $\mathrm{Cb}$ & 31 & 2.6 & 0.8 & 0.1 & 2.3 & 2.9 & a \\
\hline & F21CN & grape & $F x$ & 7 & 15.6 & 9.2 & 3.5 & 7.0 & 24.1 & b \\
\hline & F21CS & grape & $F x$ & 5 & 14.0 & 6.3 & 2.8 & 6.2 & 21.9 & $b$ \\
\hline & F28CW & grape & $\mathrm{Tt}$ & 5 & 3.3 & 1.0 & 0.5 & 2.0 & 4.6 & a \\
\hline & \multicolumn{3}{|c|}{ Crop } & $\mathrm{N}$ & mean & $\mathrm{sd}$ & $\mathrm{se}$ & $\min$ & $\max$ & $p<0.05$ \\
\hline \multirow{4}{*}{ ๓ } & \multirow{3}{*}{\multicolumn{3}{|c|}{$\begin{array}{c}\text { Alfalfa } \\
\text { Wine Grapes } \\
\text { Fallow }\end{array}$}} & $\overline{6}$ & $\overline{5.7}$ & 1.3 & 0.5 & 4.3 & 7.1 & $\bar{a}$ \\
\hline & & & & 112 & 4.4 & 4.8 & 0.5 & 3.5 & 5.3 & a \\
\hline & & & & 33 & 2.9 & 1.6 & 0.3 & 2.4 & 3.5 & a \\
\hline & Soil ID & Soil Name & Soil Description & $\mathrm{N}$ & mean & sd & $\mathrm{se}$ & $\min$ & $\max$ & $\mathrm{p}<0.05$ \\
\hline \multirow{5}{*}{ 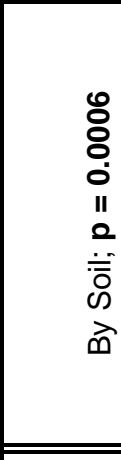 } & $\mathrm{Fu}$ & $\begin{array}{l}\text { Fresno fine sandy } \\
\text { loam }\end{array}$ & $\begin{array}{c}\text { fine sandy loam } \\
\text { over cemented }\end{array}$ & 36 & 4.1 & 2.9 & 0.5 & 3.1 & 5.1 & $\mathrm{a}$ \\
\hline & $\mathrm{Cb}$ & $\begin{array}{l}\text { Cajon loamy coarse } \\
\text { sand, saline alkali }\end{array}$ & loamy coarse sand & 31 & 2.6 & 0.8 & 0.1 & 2.3 & 2.9 & a \\
\hline & Fx & $\begin{array}{l}\text { Fresno-Traver } \\
\text { complex }\end{array}$ & $\begin{array}{c}\text { Fine sandy loam } \\
\text { over silt }\end{array}$ & 46 & 6.3 & 6.6 & 1.0 & 4.3 & 8.2 & $b$ \\
\hline & $\mathrm{Pt}$ & $\begin{array}{l}\text { Pond fine sandy } \\
\text { loam }\end{array}$ & $\begin{array}{c}\text { fine sandy } \\
\text { loam/clay loam }\end{array}$ & 33 & 2.9 & 1.6 & 0.3 & 2.4 & 3.5 & a \\
\hline & $\mathrm{Tt}$ & $\begin{array}{l}\text { Traver fine sandy } \\
\text { loam }\end{array}$ & $\begin{array}{c}\text { fine sandy } \\
\text { loam/clay loam }\end{array}$ & 5 & 3.3 & 1.0 & 0.5 & 2.0 & 4.6 & $a b$ \\
\hline \multicolumn{4}{|c|}{ Total } & 151 & 4.2 & 4.2 & 0.3 & 3.5 & 4.8 & \\
\hline
\end{tabular}

Table 5. $\quad$ Field Infiltration Summary

\begin{tabular}{|l|c|c|cc|cc|}
\hline Check & $\mathrm{N}^{1}$ & $\begin{array}{c}\text { Infiltration } \\
\text { Rates } \\
\text { In/day }\end{array}$ & $\begin{array}{c}\text { Daily total } \\
\mathrm{Ft}\end{array}$ & $\begin{array}{c}\text { Season } \\
\text { Total } \\
\text { Ft }\end{array}$ & $\begin{array}{c}\text { Estimated Depth of Infiltration (ft) for Min } \\
\text { and Max Available Water Content (\%) }\end{array}$ \\
\cline { 6 - 7 } & & 3.8 & 0.26 & 7.8 & 0.08 & 0.14 \\
\hline \hline F16CN & 30 & 15.8 & 0.41 & 2.8 & 38 & 20 \\
F21CN & 7 & 14.2 & 0.51 & 2.6 & 32 & 18 \\
F21CS & 5 & 3.3 & 0.28 & 9.5 & 118 & 68 \\
F22CN & 34 & 2.7 & 0.20 & 6.2 & 78 & 45 \\
F22CS & 31 & 2.7 & 0.11 & 2.6 & 32 & 18 \\
F24CN & 23 & 2.7 & 0.57 & 2.9 & 36 & 20 \\
F28CW & 5 & 3.5 & 0.16 & 1.6 & 20 & 11 \\
F32C2 & 10 & 3.5 & 2.1 & 26 & 15 \\
F07 & 6 & 6.0 & 0.34 & 2.1 &
\end{tabular}

Notes

$1 \quad$ Number of infiltration events. Each event is roughly one day long. 
On-Farm Flood Flow Capture As a Cost Effective Method to Recharge Groundwater and Reduce Downstream Flood Risks

Agreement No. 68-9104-128

Table 6. $\quad$ Acre Feet Applied by Crop and Field

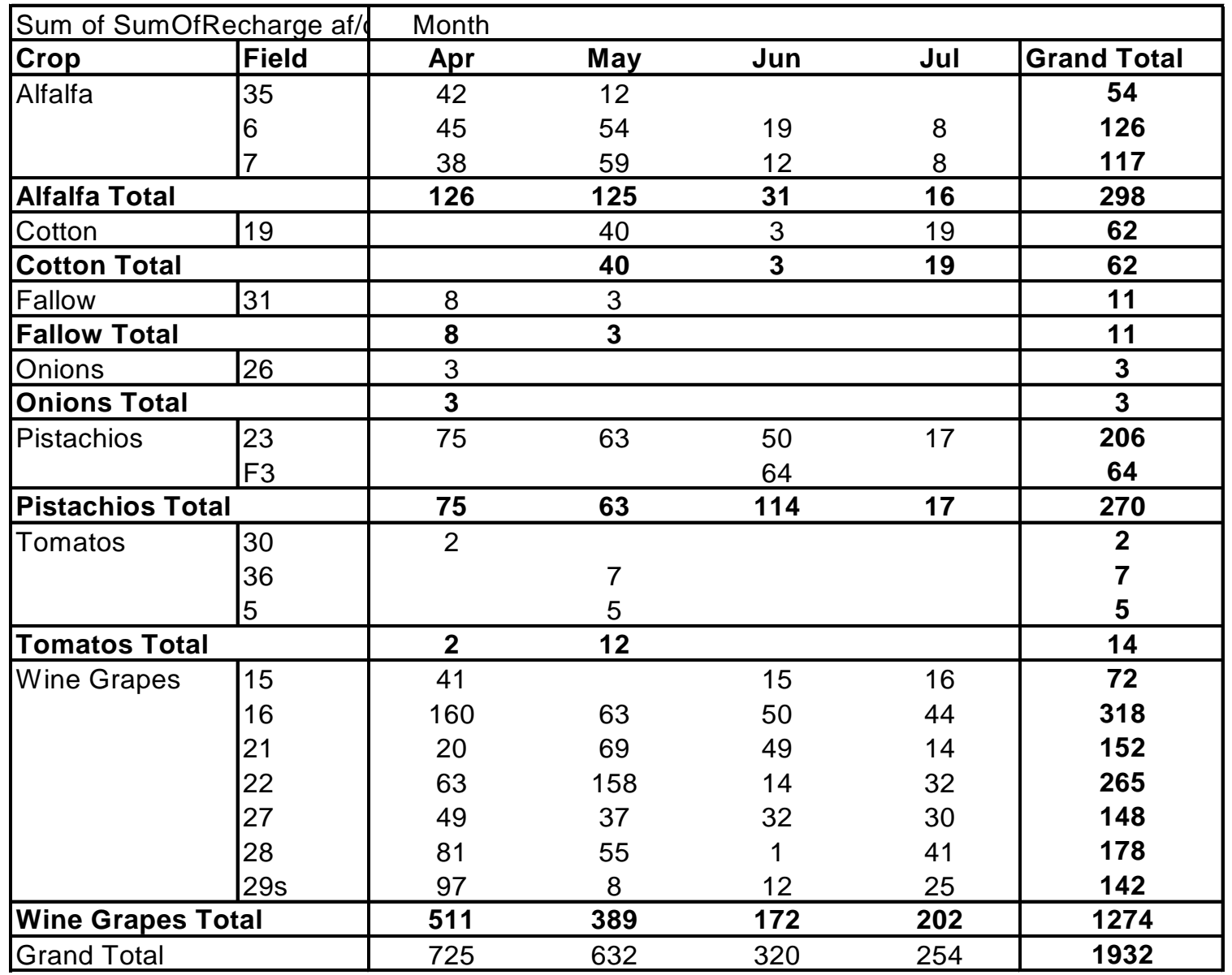


On-Farm Flood Flow Capture As a Cost Effective Method to Recharge Groundwater and Reduce Downstream Flood Risks

Agreement No. 68-9104-128

\section{Table 7. Field water budget}

Data from $1 / 1 / 2011$ thru $7 / 14 / 2011$. Fields shown are those with $>2$ inches of water applied from flood flows.

\begin{tabular}{|c|c|c|c|c|}
\hline & Precip (in) & ETC (in) & Applied Water (in) & Total (in) \\
\hline Alfalfa & 13.6 & -116.9 & 64.1 & -39.2 \\
\hline 35 & 4.5 & -39.0 & 25.5 & -8.9 \\
\hline 6 & 4.5 & -39.0 & 20.9 & -13.5 \\
\hline 7 & 4.5 & -39.0 & 17.7 & -16.7 \\
\hline Cotton & 4.5 & -15.3 & 8.5 & -2.3 \\
\hline 19 & 4.5 & -15.3 & 8.5 & -2.3 \\
\hline miscellaneous & 4.5 & -32.6 & 2.1 & -25.9 \\
\hline 31 & 4.5 & -32.6 & 2.1 & -25.9 \\
\hline Pistachios & 9.0 & -51.7 & 40.4 & -2.3 \\
\hline 23 & 4.5 & -25.8 & 30.3 & 9.0 \\
\hline F3 & 4.5 & -25.8 & 10.1 & -11.3 \\
\hline Tomatos & 13.6 & -59.7 & 15.0 & -31.0 \\
\hline 32 & 4.5 & -21.5 & 7.2 & -9.8 \\
\hline 36 & 4.5 & -22.0 & 3.7 & -13.8 \\
\hline 5 & 4.5 & -16.1 & 4.2 & -7.4 \\
\hline Wine Grapes & 31.6 & -137.2 & 205.6 & 100.1 \\
\hline 15 & 4.5 & -19.6 & 14.6 & -0.5 \\
\hline 16 & 4.5 & -19.6 & 55.4 & 40.3 \\
\hline 21 & 4.5 & -19.6 & 21.7 & 6.6 \\
\hline 22 & 4.5 & -19.6 & 44.1 & 29.0 \\
\hline 27 & 4.5 & -19.6 & 23.0 & 7.9 \\
\hline 28 & 4.5 & -19.6 & 28.2 & 13.1 \\
\hline $29 \mathrm{~s}$ & 4.5 & -19.6 & 18.7 & 3.6 \\
\hline Grand Total & 76.8 & -413.3 & 335.9 & -0.6 \\
\hline Notes & & & & \\
\hline
\end{tabular}


On-Farm Flood Flow Capture As a Cost Effective Method to Recharge Groundwater and Reduce Downstream Flood Risks

Agreement No. 68-9104-128

Table 8. Monthly Water Budget for three key crops

Crops shown were primary crops receiving flood flows. Flood flows were diverted to crops from mid-Jan through mid-July, 2011.

\begin{tabular}{|c|c|c|c|c|}
\hline & Precip (inches) & ETC (inches) & Flood Flows (inches) & Total (inches) \\
\hline Alfalfa & 0.6 & -5.6 & 6.4 & -2.6 \\
\hline 1 & 0.9 & -1.2 & & -0.3 \\
\hline 2 & 0.7 & -2.7 & & -2.0 \\
\hline 3 & 1.8 & -3.9 & & -2.1 \\
\hline 4 & 0.2 & -6.9 & 10.2 & 1.0 \\
\hline 5 & 0.3 & -9.1 & 8.7 & -2.3 \\
\hline 6 & 0.6 & -9.8 & 2.5 & -7.9 \\
\hline 7 & 0.0 & -5.3 & 1.2 & -4.7 \\
\hline$\Xi$ Pistachios & 0.6 & -3.7 & 8.1 & -0.2 \\
\hline 1 & 0.9 & -0.5 & & 0.4 \\
\hline 2 & 0.7 & -1.0 & & -0.3 \\
\hline 3 & 1.8 & -1.4 & & 0.4 \\
\hline 4 & 0.2 & -2.6 & 9.8 & 2.6 \\
\hline 5 & 0.3 & -5.7 & 9.9 & -0.5 \\
\hline 6 & 0.6 & -9.4 & 9.0 & 0.2 \\
\hline 7 & 0.0 & -5.3 & 2.7 & -3.9 \\
\hline$\boxminus$ Wine Grapes & 0.6 & -2.8 & 5.9 & 1.5 \\
\hline 1 & 0.9 & -0.3 & 0.5 & 0.9 \\
\hline 2 & 0.7 & -0.6 & 1.6 & 0.7 \\
\hline 3 & 1.8 & -1.0 & 4.8 & 1.4 \\
\hline 4 & 0.2 & -2.7 & 10.7 & 6.9 \\
\hline 5 & 0.3 & -4.8 & 10.2 & 3.1 \\
\hline 6 & 0.6 & -6.6 & 3.5 & -2.9 \\
\hline 7 & 0.0 & -3.6 & 4.7 & 0.5 \\
\hline
\end{tabular}


Table 9. $\quad$ Farm Costs Summary from January through July, 2012.

\begin{tabular}{|c|c|c|c|c|c|}
\hline \multirow{2}{*}{\begin{tabular}{|r} 
Category \\
Raw Costs Data
\end{tabular}} & \multirow[t]{2}{*}{ Description } & \multicolumn{3}{|c|}{ Amount } & \multirow[t]{2}{*}{ Units } \\
\hline & & Recurring $^{2}$ & One-time $^{3}$ & Total & \\
\hline Wages & Land preparation, water management, & 18,545 & 0 & 18,545 & $\$$ \\
\hline $\mathrm{OH}$ & Taxes, insurance, admin and other & 6,491 & 0 & 6,491 & $\$$ \\
\hline Contracted Services & Leveling, repairs & 1,500 & 0 & 1,500 & $\$$ \\
\hline Pump Rental & 3 pumps (3600 - 5000 gpm) & 25,479 & 0 & 25,479 & $\$$ \\
\hline Conveyance & Weirs, irrigation pipe system & 6,969 & 28,780 & 35,749 & $\$$ \\
\hline Diesel & Lift Pumps & 29,986 & 0 & 29,986 & $\$$ \\
\hline \multicolumn{2}{|l|}{ Total one-year costs } & 88,969 & 28,780 & 117,749 & $\$$ \\
\hline \multicolumn{6}{|c|}{ Standarized against water use for current year } \\
\hline Diverted Water & Acre-feet & & & 3,116 & ac-ft \\
\hline Total per Acre-Feet & \$/Acre-feet & 29 & 9 & 38 & \$/ac-ft \\
\hline \multicolumn{6}{|c|}{ Standardized against 25-year water use with equivalent volumes } \\
\hline Reoccurence Interval & Expected frequency of flood flows for & & & 2 & yrs \\
\hline Number of episodes & Number of flood events expected to be & & & 13 & \# \\
\hline Expected Volume & Diverted water equivalent to pilot year & & & 3,116 & ac-ft \\
\hline Total for 25 year period & & $1,156,602$ & 28,780 & $1,185,382$ & $\$$ \\
\hline Fixed Costs (20\%) 5 & & 231,320 & 5,756 & 237,076 & $\$$ \\
\hline Total Costs $(25$ year + & & $1,387,923$ & 34,536 & $1,422,459$ & $\$$ \\
\hline Volume Captured & Volume captured with equivalent system & & & 40,508 & ac-ft \\
\hline Costs per Ac-Ft (25- & & 34 & 1 & 35 & \$/ac-ft \\
\hline \multicolumn{6}{|c|}{ Standarized against utilized acres for recharge } \\
\hline Primary Acreage Used & Fields 16, 22, 28 (acres) & & & 225 & ac \\
\hline
\end{tabular}

\section{Notes}

1. Does not include profit

2. Cost will be incurred in preparation of flood capture period

3. Costs are one-time infrastructure upgrades

4. Costs standardized to ac-ft captured assumes equivalent effort over 25 years.

5. Fixed costs assumed to be $20 \%$ of all other costs. 
On-Farm Flood Flow Capture As a Cost Effective Method to Recharge Groundwater and Reduce Downstream Flood Risks

Agreement No. 68-9104-128

Table 10. Summary of hydrologic characteristics of soil series

Based upon data from Custom Soil Series Report

\begin{tabular}{|c|c|c|c|c|c|c|c|c|}
\hline Soils & $\begin{array}{c}\text { General } \\
\text { Description }\end{array}$ & Drainage & $\begin{array}{l}\text { Hydrologic } \\
\text { Group }\end{array}$ & $\begin{array}{c}\text { Infiltration } \\
\text { summary }\end{array}$ & $\begin{array}{c}\text { Restrictive } \\
\text { Layer }\end{array}$ & $\begin{array}{c}\text { Depth to } \\
\text { Restrictive } \\
\text { Layer (in) }\end{array}$ & $\begin{array}{c}\text { Ksat } \\
\text { (in/hr) }\end{array}$ & $\begin{array}{c}\text { Avail } \\
\text { Water Cap }\end{array}$ \\
\hline Fs & $\begin{array}{c}\text { sandy loam over } \\
\text { cemented }\end{array}$ & $\begin{array}{c}\text { Somewhat poorly } \\
\text { drained / }\end{array}$ & $C$ & very limited & duripan & $20-36$ & $0.00-0.01$ & Very low \\
\hline Fw & $\begin{array}{l}\text { Clay loam over } \\
\text { cemented }\end{array}$ & $\begin{array}{c}\text { Somewhat poorly } \\
\text { drained/ }\end{array}$ & D & very limited & duripan & $10-20$ & $0.00-0.01$ & Very low \\
\hline $\mathrm{Fu}$ & $\begin{array}{c}\text { fine sandy loam } \\
\text { over cemented }\end{array}$ & $\begin{array}{c}\text { Somewhat poorly } \\
\text { drained / }\end{array}$ & C & very limited & duripan & $20-36$ & $0.00-0.01$ & Very low \\
\hline$F x$ & $\begin{array}{c}\text { Fine sandy load } \\
\text { over silt }\end{array}$ & $\begin{array}{l}\text { Somewhat poorly } \\
\text { drained / }\end{array}$ & C & very limited & duripan & $20-36$ & $0.00-0.01$ & Very low \\
\hline CfA & loamy sand/sand & $\begin{array}{l}\text { Somewhat } \\
\text { excessively drained }\end{array}$ & A & not limited & & $>80$ & $6-20$ & Low \\
\hline CfB & loamy sand/sand & $\begin{array}{l}\text { Somewhat } \\
\text { excessively drained }\end{array}$ & A & $\begin{array}{l}\text { Somewhat } \\
\text { limited }\end{array}$ & & $>80$ & $6-20$ & Low \\
\hline HsE & & $\begin{array}{l}\text { Somewhat } \\
\text { excessively drained }\end{array}$ & B & $\begin{array}{l}\text { Somewhat } \\
\text { limited }\end{array}$ & & $>80$ & $6-20$ & Moderate \\
\hline Pt & $\begin{array}{c}\text { fine sandy } \\
\text { loam/clay loam }\end{array}$ & $\begin{array}{c}\text { Somewhat poorly } \\
\text { drained / }\end{array}$ & D & very limited & clay & $17-20$ & $0.06-0.20$ & low \\
\hline PfB & sandy loam & $\begin{array}{c}\text { Somewhat poorly } \\
\text { drained/ }\end{array}$ & B & Very limited & & $>80$ & $0.57-2$ & Low \\
\hline $\mathrm{PgB}$ & fine sandy loam & $\begin{array}{c}\text { Somewhat poorly } \\
\text { drained/ }\end{array}$ & B & Very limited & & $>80$ & $0.57-2$ & Low \\
\hline Ro & fine sandy loam & $\begin{array}{l}\text { Somewhat poorly } \\
\text { drained/ }\end{array}$ & $\mathrm{D}$ & Very limited & & $>80$ & $0.06-0.20$ & Moderate \\
\hline Tt & $\begin{array}{c}\text { fine sandy } \\
\text { loam/clay loam }\end{array}$ & Well drained & D & Very limited & & $>80$ & $0.06-0.20$ & Low \\
\hline
\end{tabular}


On-Farm Flood Flow Capture As a Cost Effective Method to Recharge Groundwater and Reduce Downstream Flood Risks

Agreement No. 68-9104-128

Table 11. Pumped groundwater quality at a sample of Terranova Ranch wells, 2007 2009

\begin{tabular}{|c|c|c|c|c|}
\hline & $\mathrm{EC}(\mathrm{ds} / \mathrm{m})$ & $\mathrm{NO}_{3}\left(\mathrm{mg} \mathrm{NO}{ }_{3}-\mathrm{N} / \mathrm{L}\right)$ & TDS $(\mathrm{mg} / \mathrm{L})^{1}$ & ECe stds $(\mathrm{ds} / \mathrm{m})^{4}$ \\
\hline mean & 1.02 & 3.13 & 978 & \\
\hline median & 0.80 & 1.65 & 764 & \\
\hline $\max$ & 2.95 & 11.10 & 2817 & $3^{2}$ \\
\hline 75th Percentile & 1.25 & 5.38 & 1191 & \\
\hline 66th Percentile & 1.03 & 3.63 & 981 & $1^{3}$ \\
\hline 25th quartile & 0.8 & 1.65 & 764 & \\
\hline $\min$ & 0.32 & 0.10 & 306 & \\
\hline SD & 0.63 & 3.44 & 601 & \\
\hline $\mathrm{N}$ & 30.00 & 30.00 & & \\
\hline \multicolumn{5}{|l|}{ Notes } \\
\hline \multicolumn{5}{|c|}{ 1. Estimated from conversion factor developed from Ranch data } \\
\hline \multicolumn{5}{|c|}{ 2. Soil salinity below $3 \mathrm{dS} / \mathrm{m}$ for moderately sensitive crops (Ayers and Westcott, 1994) } \\
\hline \multicolumn{5}{|c|}{ 3. Soil salinity below $1 \mathrm{ds} / \mathrm{M}$ for slightly sensitive crops (Ayers and Westcott, 1994} \\
\hline \multicolumn{5}{|c|}{ 4. Recommended soil salinity standards by Ayers and Westcott to maintain $100 \%$ yields } \\
\hline
\end{tabular}


On-Farm Flood Flow Capture As a Cost Effective Method to Recharge Groundwater and Reduce Downstream Flood Risks

Agreement No. 68-9104-128

\section{Table 12. Salt Mass Budget from Profile}

Mass budget is estimated from data collected in this report and using assumptions detailed in the text.

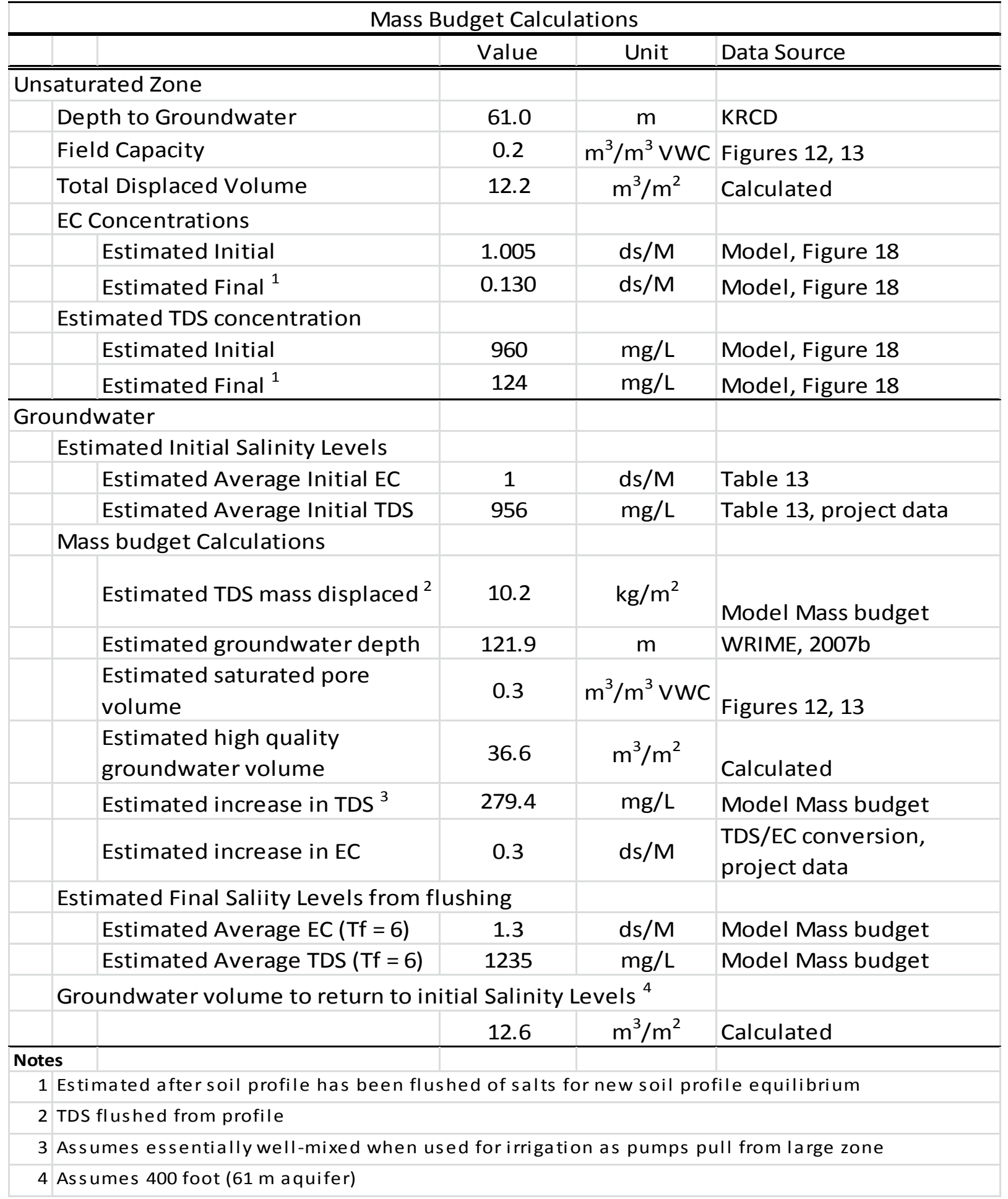


On-Farm Flood Flow Capture As a Cost Effective Method to Recharge Groundwater and Reduce Downstream Flood Risks

Agreement No. 68-9104-128

Table 13. Infiltration Acres to Capture Flood Flows past the James Bypass for Soils of Different Hydrologic Groups

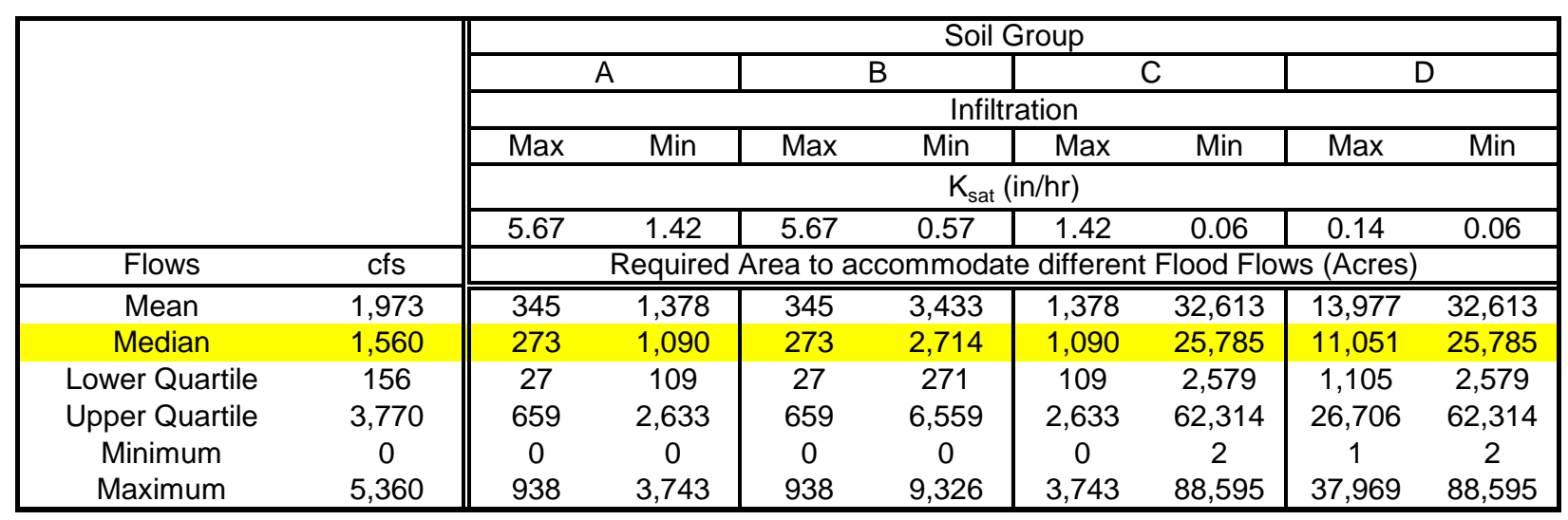


On-Farm Flood Flow Capture As a Cost Effective Method to Recharge Groundwater and Reduce Downstream Flood Risks

Agreement No. 68-9104-128

Table 14. Local and Regional Logistical Issues

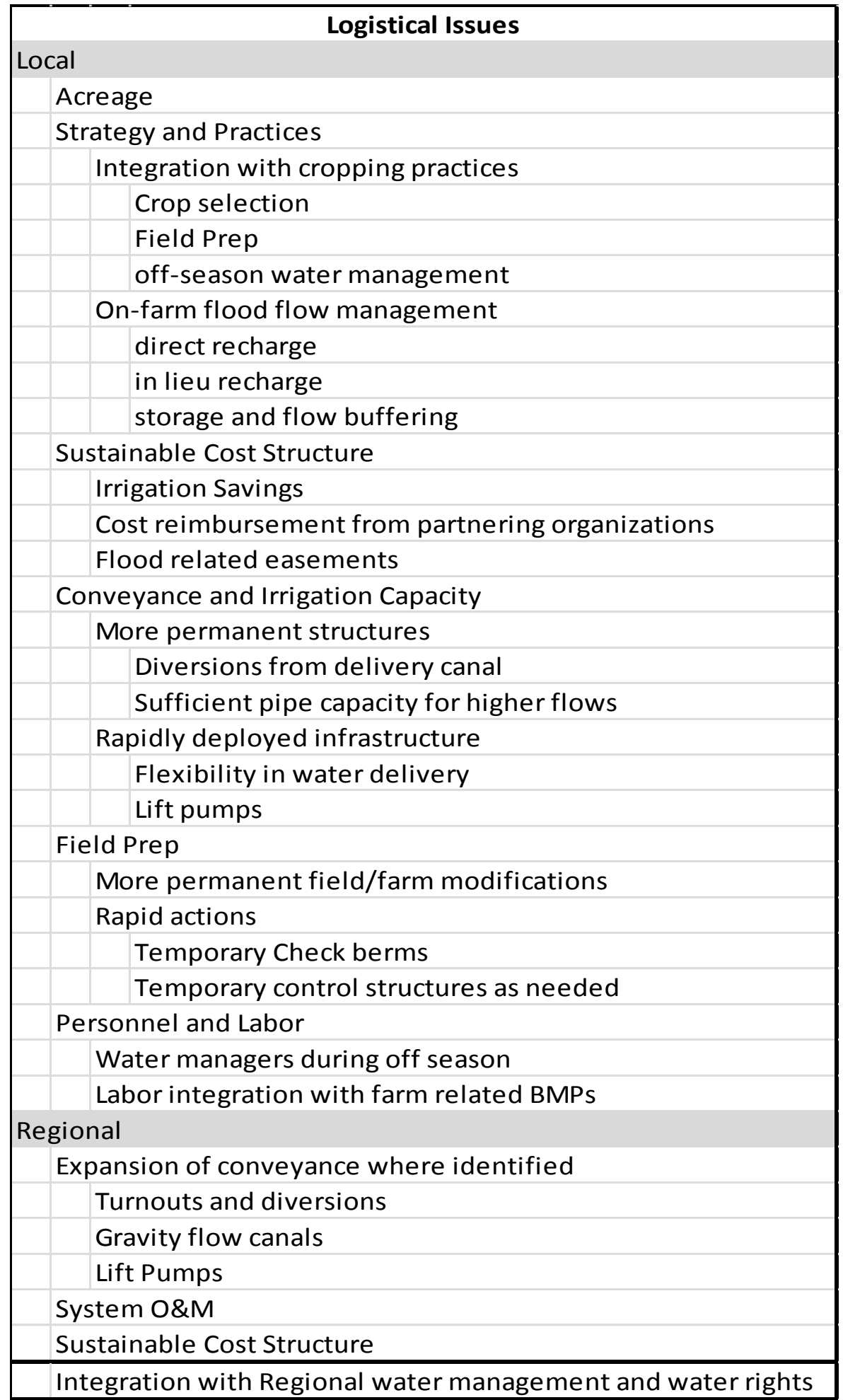


On-Farm Flood Flow Capture As a Cost Effective Method to Recharge Groundwater and Reduce Downstream Flood Risks

Agreement No. 68-9104-128

Table 15. Recurrence Intervals and Flows for High Flow in the Kings River

\begin{tabular}{|l|cccc|}
\hline $\begin{array}{l}\text { Minimum Flow } \\
\text { (CFS) }\end{array}$ & $\begin{array}{c}\text { Average Flow during } \\
\text { Period (CFS) }\end{array}$ & $\begin{array}{c}\text { Recurrence Interval } \\
\text { (yrs) }\end{array}$ & $\begin{array}{c}\text { Average Duration } \\
\text { (days) }\end{array}$ & $\begin{array}{c}\text { Median Duration } \\
\text { (days) }\end{array}$ \\
\hline 0 & 1,324 & 2.0 & 104 & 77 \\
4,000 & 4,459 & 3.8 & 45 & 29 \\
4,750 & 4,866 & 7.0 & 33 & 11 \\
\hline
\end{tabular}

